\title{
Geochemistry of Maastrichtian Clastic Sedimentary Rocks from Western Flank of Anambra Basin, Nigeria: Implications for Provenance, Tectonic Setting, Paleoclimate and Depositional Paleoenvironment
}

\author{
Osazuwa Abifade Ogbahon*, Oluwafemi Babajide Olujinmi \\ Department of Applied Geology, The Federal University of Technology, Akure, Ondo State, Nigeria \\ Email: *oaogbahon@futa.edu.ng
}

How to cite this paper: Ogbahon, O.A. and Olujinmi, O.B. (2019) Geochemistry of Maastrichtian Clastic Sedimentary Rocks from Western Flank of Anambra Basin, Nigeria: Implications for Provenance, Tectonic Setting, Paleoclimate and Depositional Paleoenvironment. International Journal of Geosciences, 10, 91-118.

https://doi.org/10.4236/ijg.2019.101007

Received: November 29, 2018

Accepted: January 28, 2019

Published: January 31, 2019

Copyright $\odot 2019$ by author(s) and Scientific Research Publishing Inc. This work is licensed under the Creative Commons Attribution International License (CC BY 4.0).

http://creativecommons.org/licenses/by/4.0/

\begin{abstract}
The geochemistry, provenance, tectonic setting, paleoclimate and depositional paleoenvironment of Maastrichtian clastic sedimentary rocks from the western flank of Cretaceous-Tertiary intracratonic Anambra Basin, Nigeria have been studied through major and trace element geochemical analysis. Ten (10) representatives outcrop samples collected from two stratigraphic sections in the study area were analyzed chemically using Inductively Coupled Plasma Atomic Emission Spectroscopy, ICP-AES (Lithium Borate Fusion). The geochemical data shows that the sediments are enriched in major oxides including $\mathrm{SiO}_{2}, \mathrm{Al}_{2} \mathrm{O}_{3}, \mathrm{Fe}_{2} \mathrm{O}_{3}$ and $\mathrm{TiO}_{2}$ but depleted in other major element oxides. Also, the sandstones have higher concentrations in $\mathrm{SiO}_{2}, \mathrm{CaO}$ and $\mathrm{Na}_{2} \mathrm{O}$ compared to the associated mudrocks whereas the mudrocks are more enriched in $\mathrm{Al}_{2} \mathrm{O}_{3}, \mathrm{Fe}_{2} \mathrm{O}_{3}, \mathrm{MgO}, \mathrm{K}_{2} \mathrm{O}, \mathrm{TiO}_{2}$ and $\mathrm{P}_{2} \mathrm{O}_{5}$ compared to the sandstones. The mudrock samples have higher concentration of $\mathrm{Ba}, \mathrm{Ni}, \mathrm{Sr}, \mathrm{Y}$, $\mathrm{Nb}, \mathrm{Sc}$ in comparison to sandstones. However, sandstone samples have higher concentration in $\mathrm{Zr}(1098.50 \mathrm{ppm})$ than the mudrocks (1038 ppm). The sandstones are classified as litharenites, sublitharenites, Fe-rich sandstones, while the mudrocks are labeled as shale and Fe-rich shale based on chemical composition. Analysis of the data shows a dominantly felsic igneous to intermediate igneous and quartzose sedimentary provenances of mixed granite and granodiorite composition as indicated by various discriminant plots. The inferred provenance is corroborated by the low concentrations of $\mathrm{Cr}, \mathrm{Ni}$ and $\mathrm{Sc}$ in the samples and other proxies. On the basis of various tectonic setting discriminant function diagrams, the Maastrichtian sediments from the study
\end{abstract}


area were deposited on passive margin tectonic setting that developed consequent to the breakup of Gwandana supercontinent but was later affected by tectonism in Santonian times. The alteration feldspars to smectite and kaolinite as depicted by the A-CN-K ternary diagram alongside the high values of chemical index of alteration (CIA, 87.38 - 98.09) and chemical index of weathering (CIW, 89.22 - 99.90) indicates paleogeographic setting characterized by warm and humid/tropical paleoclimatic condition where there was prevalence of intense chemical weathering. The low values of $\mathrm{Sr} / \mathrm{Ba}$ ratio (0.31 0.70 ) suggest sediment deposition in continental to deltaic paleoenvironment.

\section{Keywords}

Geochemistry, Anambra Basin, Provenance, Paleoclimate

\section{Introduction}

The study area with geographic coordinates defined by latitudes $7^{\circ} 07^{\prime} \mathrm{N}$ and $7^{\circ} 13^{\prime} \mathrm{N}$ longitudes $6^{\circ} 21^{\prime} \mathrm{E}$ and $6^{\circ} 31^{\prime} \mathrm{E}$ is situated on the western flank of Anambra Basin in southern Nigeria. The outcropping sedimentary successions investigated in the current study display the characteristics of Mamu Formation (Figure 1). The Anambra Basin is a Mesozoic-Cenozoic petroliferous and coal-bearing basin located within the southern Benue Trough which evolution is related to the opening of the Gulf of Guinea and the separation of African and South American Plates sequel to the breakup of Gwandana supercontinent during Late Jurassic to Early Cretaceous times. The NE-SW oriented basin has a roughly triangular outline and covers about $40,000 \mathrm{Km}^{2}$ [1] with sedimentary thickness of over $5000 \mathrm{~m}$. The basinal fill consists of a wide spectrum of lithologies both in lateral and temporal relationships including limestone, marl, shale, coal, sandstone and siltstone. The occurrence of favorable stratigraphic architecture of interbedded sandstones and shales alongside sparse limestones [2] in the southern Benue Trough spurred the first interest for hydrocarbon exploration in the early 1900s. The effort was rewarded by the discovery of commercial coal deposit in the Anambra Basin in 1916. The initial discovery of petroleum was not in commercial quantity. The later discovery of commercial quantity of hydrocarbon in contiguous Niger Delta in 1956 by Shell D Arcy rekindled research interests of authors to extend the exploration efforts to other basins in Nigeria, including Anambra Basin. These efforts have led the discovery of commercial quantity hydrocarbon in the basin. Consequently, there are plethora of publications on petroleum geochemical studies [e.g. [3] [4] [5] [6] [7]] of Anambra Basin available in literature. There is however a dearth of publications on provenance studies in the basin. The few available provenance studies [e.g. [8] [9]] applied the petrographic approach which allows one to make deductions only from analysis of modal composition of the framework grains of sandstones or coarse-grained sediments while excluding the matrix component and the as- 
sociated mudrocks in the stratigraphic section. According to Eynatten1 et al. [10], petrographic provenance study is prone to high methodical errors (counting statistics) in the quantification of individual variables. Furthermore, the mineralogical and chemical composition of coarse grained sedimentary rocks frequently used for petrographic analysis may be significantly different from that of the parent material because of the effect of hydraulic sorting of grains controlled by grain size, grain shape and density of sedimentary particles. In consideration of the aforementioned reasons, Blatt [11] and Roser and Korsch [12] suggested that mudrocks and shale should be used more extensively in provenance study.

The sedimentary fill of a basin is controlled by a complex interplay between sediment supply, tectonic subsidence and sea level fluctuations and preserves the record of source rock composition, paleoclimate, paleogeography and tectonic history. The importance of geochemical provenance interpretations cannot be overemphasized. It provides useful information that permits better insight into the evolutionary history of a basin and it is an integral part of basin analysis. Basin analysis is an integrated programme of study that involves application of sedimentologic, stratigraphic, and tectonic principles to develop a full understanding of the rocks that fill sedimentary basins and to use this information to interpret the geologic history and evaluate the economic importance of these rocks [13]. According to Jian et al. [14] provenance analysis has industrial implications such as helping to evaluate the relationship between source and sink, discriminating sedimentary systems and depositional areas and thus facilitating oil and gas exploration. Inorganic geochemical study of sediments is an important tool in the determination of provenance, environment of deposition and paleo-weathering at source area. In addition, it serves as major tool in the discrimination of tectonic settings. According to Herron and Herron [15], the introduction of modern chemical analytical techniques (X-ray fluorescence, energy dispersive X-ray spectrometry, and atomic absorption spectrometry, and so many more) has enabled a large number of high-quality chemical analyses of rocks, including sandstones and shale, to become available without corresponding detailed petrographic study. Despite its usefulness however, provenance analysis of analysis of Anambra basin fill has received only little attention. This study therefore seeks to utilize major and trace element geochemical analysis to unravel the provenance, tectonic setting and paleoclimatic conditions of sediments of Mamu Formation exposed in parts of the western flank of Anambra Basin.

\section{Geology and Stratigraphy of Anambra Bsasin}

The study area is situated in the western part of Anambra Basin (Figure 1 \& Figure 2). The basin is one of the structural features of the Southern Benue Trough. Topographically seen as roughly triangular shaped NE-SW trending siliciclastic wedge, Anambra Basin covers an area of about $40,000 \mathrm{~km}^{2}$ with sediment thickness increasing southwards to maximum of roughly $6000 \mathrm{~m}$ [1]. The 


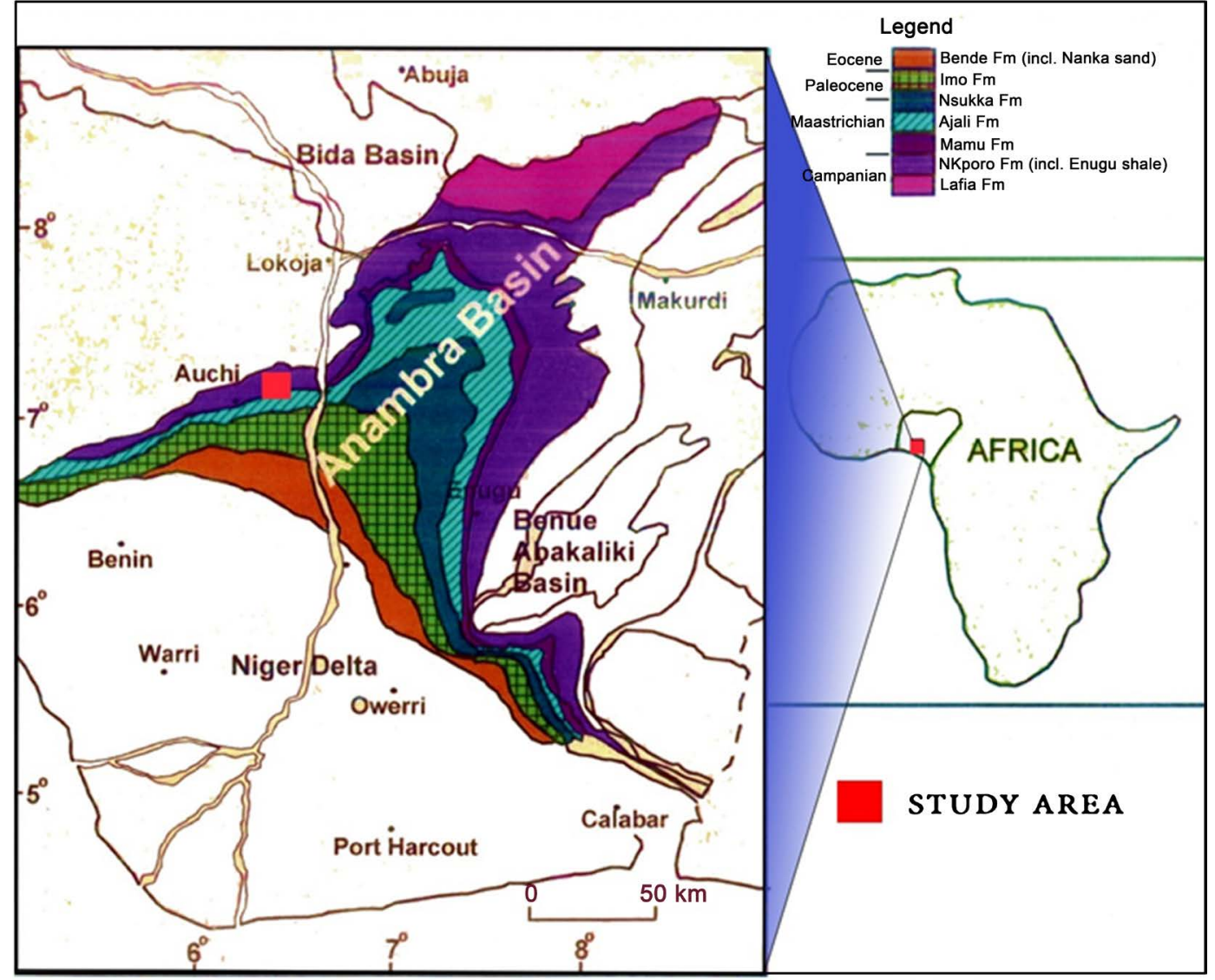

Figure 1. Geologic map of the Southern Benue Trough and Anambra Basin showing the location of the study area (modified after Nwajide and Reijers, [1]).

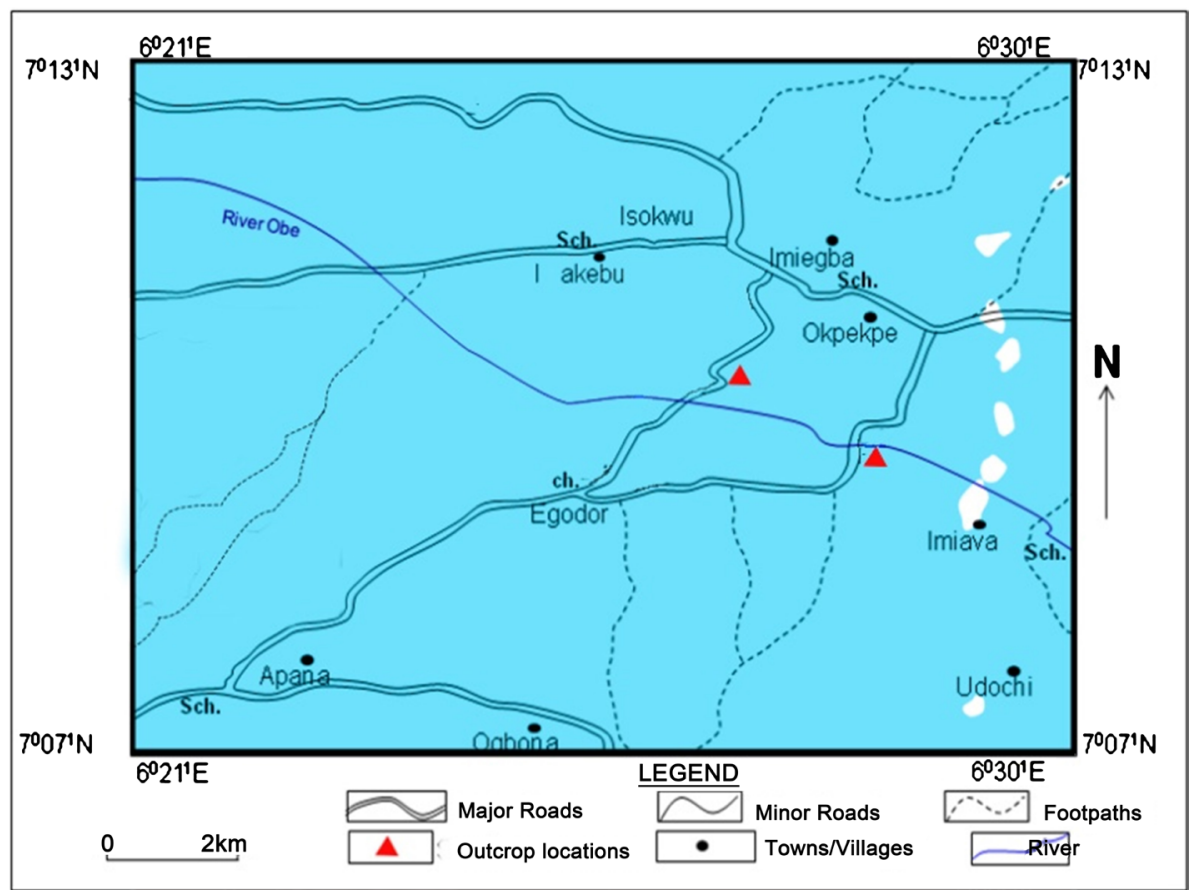

Figure 2. Road and drainage map of the study area showing the location of outcrop exposures as red triangles (Modified from Federal Survey map, Nigeria). 
Benue Trough is Nigeria's portion of the regionally extensive Central Africa Rift System that evolved in response to extensional block faulting and crustal subsidence subsequent to Late Jurassic to Early Cretaceous breakup of the Gwandana supercontinent [16]. The event culminated in the separation of African and South American plates, evolution of Gulf Guinea and the formation of an aulacogen, the Benue Trough as the failed arm of the rift-rift-rift (RRR) triple junction. Major transform fault zones were thought to have played significant role in the distribution and geometry of numerous subbasins although there is lack of direct evidence for their existence [2] [16]. Two major marine transgressive-regressive cycles occurred in the Benue Trough between Albian and Santonian. The first transgression began in Albian and resulted in the deposition of roughly $2000 \mathrm{~m}$ of clastic sediments of the Asu River Group [17] The Asu River Group consists of micaceous sandstones, sandy shales, siltstone, mudstones, and subordinate lenses of limestones. The succeeding regressive phase in the Cenomanian resulted in the deposition of beds of Odukpani Formation only on the Calabar flank.

The onset of the second marine transgressive-regressive cycle in the Abakaliki-Benue depression between Turonian to Coniacian resulted in the deposition of thick, dark grey fissile laminated shales, calcareous siltstones and limestones of the Eze-Aku Formation which is succeed by Turonian to Santonian thick bedded, grey-black laminated shales with interbeds of shelly limestone and fine to medium grained sandstone of the Awgu Formation deposited during the peak of marine transgression [16] [17]. Deposition in the Benue Valley was truncated by the late Santonian compressive forces, folding and uplift of the Abakaliki region, forcing the depocentre to migrate northwestward to the proto Anambra platform, causing it to subside [16] [17]. The uplifted succession of the Abakaliki Anticlinorium became the topographic provenance that sourced the bulk of the sediments in the Anambra Basin [18] [19]: Prior to the Santonian tectonic event, the proto Anambra Basin was a platform thinly draped by sediments[20]. Major sedimentation in the Anambra Basin began in the Campanian with a short marine transgression followed by regression (Figure 3). The basal lithostratigraphic unit of the Anambra Basin sedimentary sequence is the Nkporo Group, consisting of Nkporo shales, Enugu Shale and Owelli Sandstone as its lateral equivalent [21].

The Nkporo Shale is composed of dark grey, very fissile but soft shale and sandstone with occasional thin interbeds of sandy shales, sandstone and marl with Sulphur coatings [2]. The formation is highly fossiliferous, consisting of both marine and terrestrially derived fauna, characterized significantly by dominant organo-facies responsible for hydrocarbon source system [22]. The Enugu Shale is restricted to the central and northern parts of the Anambra Basin and consists of carbonaceous grey black shale and coals with interbeds of very fines and sandstone/siltstone deposited in lower flood plain and swampy environment. The Owelli Sandstone consists of massive, hard ferruginous cross-bedded 


\begin{tabular}{|c|c|c|c|}
\hline \multicolumn{2}{|r|}{ AGE } & $\begin{array}{l}\text { SOUTHERN } \\
\text { BENUE/ANAMBRA }\end{array}$ & $\begin{array}{l}\text { CYCLE OF } \\
\text { SEDIMENTATION }\end{array}$ \\
\hline \multirow[t]{2}{*}{ TERTIA RY } & EOCENE & $\begin{array}{l}\text { AMEKI/NANKA } \\
\text { FORMATION }\end{array}$ & \multirow{6}{*}{$\begin{array}{l}3^{R D} \text { CYCLE OF } \\
\text { SEDIMENTATION }\end{array}$} \\
\hline & PALEOCENE & IMO SHALE & \\
\hline \multirow{7}{*}{ 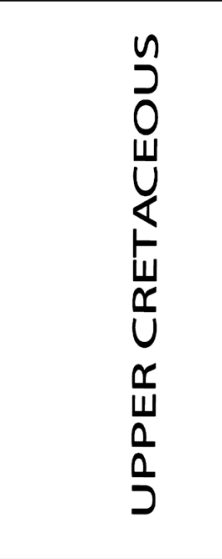 } & \multirow[t]{3}{*}{ MAASTRICHTIAN } & $\begin{array}{l}\text { NSUKKA } \\
\text { FORMATION }\end{array}$ & \\
\hline & & AJALI FORMATION & \\
\hline & & MAMU SHALE & \\
\hline & CAMPANIAN & $\begin{array}{l}\text { ENUGU/NKPORO } \\
\text { FORMATION }\end{array}$ & \\
\hline & $\begin{array}{l}\text { SANTONIAN- } \\
\text { CONIACIAN }\end{array}$ & AWGU FORMATION & \multirow{3}{*}{$\begin{array}{l}2^{\text {ND }} \text { CYCLE OF } \\
\text { SEDIMENTATION }\end{array}$} \\
\hline & TURONIAN & $\begin{array}{l}\text { EZE-AKU GROUP. } \\
\text { (KEANA, } \\
\text { MAKURDI, AGALA } \\
\text { AND AMASERI } \\
\text { FORMATIONS) }\end{array}$ & \\
\hline & CENOMANIAN & $\begin{array}{l}\text { ODUKPANI } \\
\text { FORMATION }\end{array}$ & \\
\hline \multirow{2}{*}{$\begin{array}{l}\text { LOWER } \\
\text { CRETACEOUS }\end{array}$} & ALBIAN & \multirow[b]{2}{*}{ ASU RIVER GROUP } & \multirow{2}{*}{$\begin{array}{l}1^{\text {ST }} \text { CYCLE OF } \\
\text { SEDIMENTATION }\end{array}$} \\
\hline & APTIAN & & \\
\hline
\end{tabular}

Figure 3. Stratigraphic Setting of the Anambra Basin, modified after Nwajide and Reijers [1].

sandstone. The sandstone is fine to coarse grained, poorly sorted, and may contain pebbles which are poorly sorted and well-rounded while fine grains are subrounded [2]. The sandstone contains interbeds of white to brown laminated siltstones and carbonaceous claystones and it is mineralogically mature but texturally immature [23].

Subsequent marine regression in the Maastrichtian resulted in the deposition of Mamu, Ajali and Nsukka Formations. The Maastrichtian Mamu Formation (formerly called Lower Coal Measures) consists of alternation of fine to medium grained, well sorted sandstone, dirty grey shales and sandy shale, carbonaceous shale,, siltstones, including five bituminous coal seams which range from tens of centimeters to about $3.5 \mathrm{~m}$ in thickness in Enugu area [17]. The siltstone facies contains abundant burrows of Teichichnus and Thalossinoids and other ichnogenera, mostly horizontal burrow types [17]. The coal and shale facies contain abundant fossil flora especially those of continental and freshwater origin as well as fauna, especially foraminifera such as Textularia hockleyensis, Haplophrogmoids hausa [17]. Also, frequent occurrence of channel cuts in the fine-graind sandstone facies was reported by Nwajide [17]. Coal beds together with carbonaceous shales are present towards the basal part of the formation. The occurrence of coal suggests that the formation was deposited in paludal, deltaic and possibly shallow marine settings [24]. The sedimentary succession of Mamu looks like a typical cyclotherm and is succeeded by Ajali Formation. The Ajali Formation (formerly False Bedded Sandstone) lies conformably on Mamu Formation and consists mainly of thick, friable, moderately sorted, whitish medium 
to coarse grained, burrowed sandstone, typically white with large scale occasionally clay-draped cross-bedding [25]. Odundun [26], while making reference to the work of Adegoke [27] stated that the Ajali Sandstone is a continental/fluviodeltaic sequence characterized by a regressive phase of a short-lived Maastrichtian transgression with sediments derived from westerly areas of $\mathrm{Ab}$ akaliki anticlinorium and the granitic basement units of Adamawa-Oban Massifs. The sandstone is a coarsening upward sequence in places. The Nsukka Formation conformably overlies the Ajali Sandstone. The formation occurs extensively in the Anambra Basin and marks the end of Cretaceous sedimentation in the basin. Lithologically, it consists coarse to medium grained sandstones, and passes upward into well-bedded blue clays, fine grained sandstones, and carbonaceous shales with thin bands of limestone ([28]. The shale contains significant amount of organic matter and may be potential source for the hydrocarbon in the southern part of the Niger Delta [21].

The last major marine cycle in the early Tertiary led to the deposition of $\mathrm{Pa}$ leocene Imo Shale. According to Nwajide [[17], p. 277] The extensive marine transgression that resulted in the deposition of Paleocene Imo Formation marked the termination of Anambra Basin regime and heralded the Niger Delta of which the formation is the oldest lithostratigraphic unit. The Ameki Group and the Ogwashi-Asaba Formation were deposited mainly on the Benin flank and southern part of Anambra Basin [17].

\section{Material and Methods}

Samples of mudrock and sandstone were collected from all sedimentation units during field work. Samples were studied megascopically to document the lithological and textural attributes of the rocks. Selection of rock samples for geochemical analysis was based on stratigraphic and lithologic considerations in such a manner as to capture the entire stratigraphic sections and rock types. A total number of 10 samples comprising six sandstones and four mudrocks collected from the two (2) outcrops were analyzed for their major and trace element composition using Inductively Coupled Plasma Atomic Emission Spectroscopy (ICP-AES) (Lithium Borate Fusion). Rock samples were firstly ground to powder with the aid of agate mortar and pestle at the Geochemistry Laboratory of The Federal University of Technology, Akure, Nigeria following which samples were packaged and sent to Canada.

Precisely $0.25 \mathrm{~g}$ aliquots of each sample were mixed with a flux of lithium metaborate and lithium tetra borate and fused in an induction furnace at $1000^{\circ} \mathrm{C}$. The molten melt was immediately poured into a solution of dilute $\mathrm{HNO}_{3}$. The digested samples were analyzed for their major oxides and the trace elements using ICP-AES facilities at the Mineral Laboratory of Acme Laboratories Limited, Vancouver British Columbia, Canada. The oxides of 10 major elements namely, Si, Al, Mg, Ca, Fe, K, Na, P, Mn, and Ti were analyzed. Trace elements measured were $\mathrm{Nb}, \mathrm{Ba}, \mathrm{Cr}, \mathrm{Ni}, \mathrm{Sr}, \mathrm{Zr}, \mathrm{Ni}, \mathrm{Y}$ and $\mathrm{Sc}$. Major element data is re- 
ported in normalized percentages and trace element data is reported in parts per million (ppm). Loss on ignition (LOI) was determined by igniting a sample split and then measuring the weight loss. This was done after roasting the sample at $1000^{\circ} \mathrm{C}$ for 2 hours. Quality control was guaranteed by totals ranging between 99.95 and $99.88 \mathrm{wt} \%$ for major and trace elements. Sample preparation was handled with caution to avoid sample contamination. Further details of the analytical procedures, precision, accuracy and standards used for instrumental calibration can be obtained from Acme Laboratories Limited, Vancouver, Canada.

\section{Result}

\subsection{Major Elements}

The result of geochemical analysis performed on selected rock samples from the study area is presented in Table $1 \&$ Table 2 . The bulk geochemistry of the major elements of 6 sandstone and 4 shale samples reflects the mineralogy of the samples. The sandstone samples have relatively higher $\mathrm{SiO}_{2}$ concentrations $(78.7 \%$ - 94.23\%; average $87.99 \%)$ compared to the shale samples $(38.41 \%$ $83.4 \%$; average $61.17 \%$ ). One of the shale samples (B6) has significantly low $\mathrm{SiO}_{2}$ concentration of $38.41 \%$. Comparatively, the shale samples are more enriched in $\mathrm{Al}_{2} \mathrm{O}_{3}(7.82 \%$ - 30.36\% ; average 20.73\%) compared to the sandstones $(3.51 \%$ 10.69\%; average 6.27\%). Immobile oxides like $\mathrm{Al}_{2} \mathrm{O}_{3}$ and $\mathrm{TiO}_{2}$ show slightly higher values compared to other oxide, and they even exceed the PAAS normalization value in the shale samples. $\mathrm{Al}_{2} \mathrm{O}_{3}$ and $\mathrm{K}_{2} \mathrm{O}$ indicate the occurrence of potassium feldspars, mica and clay minerals like smectite and kaolinite. All the associated shale or mudstone are relatively enriched in $\mathrm{Fe}_{2} \mathrm{O}_{3}, \mathrm{MgO}, \mathrm{K}_{2} \mathrm{O}, \mathrm{TiO}_{2}$ and $\mathrm{P}_{2} \mathrm{O}_{5}$ (average 3.56\%, 0.18\%, 0.7\%, 1.34\% and $0.09 \%$ respectively) in comparison with the sandstones (average $1.71 \%, 0.03 \%, 0.23 \%, 0.74 \%$ and $0.05 \%$ respectively) indicating their higher concentrations in shale. On the contrary, the sandstone samples have higher concentrations of $\mathrm{CaO}$ and $\mathrm{Na}_{2} \mathrm{O}$ (average $0.08 \%$ and $0.11 \%$ ) compared to the shale samples (average $0.03 \%$ and $0.03 \%$ ). An increase in the abundance of Fe-bearing clay minerals or iron oxide minerals like magnetite, leucoxene can result in high concentration of $\mathrm{Fe}_{2} \mathrm{O}_{3}$. Both the sandstone and shale samples are strongly depleted in $\mathrm{MnO}$ and $\mathrm{P}_{2} \mathrm{O}_{5}$, and there are no significant differences in their concentrations among samples. By comparison with the average upper continental crust (UCC) and Post Achaean Australian shale (PAAS), which represents continentally derived sediments [29] [30], the sandstones are enriched in $\mathrm{SiO}_{2}$ while the shale are slightly depleted in $\mathrm{SiO}_{2}$. However, one of the shale samples (B10) has $\mathrm{SiO}_{2}$ concentration of $70.57 \%$ which is higher than the average UCC and PAAS. The sandstones are highly depleted in $\mathrm{Al}_{2} \mathrm{O}_{3}$ with respect to average UCC and PAAS values, whereas the shales are enriched in $\mathrm{Al}_{2} \mathrm{O}_{3}$. One of the shale samples (B6) has significantly higher concentration of $\mathrm{Al}_{2} \mathrm{O}_{3}(30.36 \%)$ with respect to both average UCC and PAAS values. An increase in the abundance of Fe-bearing clay mineral or iron oxide minerals like magnetite, leucoxene can result in high concentration of 
Table 1. Major element concentrations (wt\%) of samples from Upper Maastrichtian Mamu Formation on the western flank of Anambra Basin.

\begin{tabular}{|c|c|c|c|c|c|c|c|c|c|c|c|c|c|c|c|c|c|c|}
\hline \multirow[b]{2}{*}{ Analyte } & \multicolumn{7}{|c|}{ Sandstone } & \multirow[b]{2}{*}{$\min$} & \multirow[b]{2}{*}{$\max$} & \multirow[b]{2}{*}{ PAAS } & \multirow[b]{2}{*}{ UCC } & \multirow[b]{2}{*}{ B1 } & \multirow[b]{2}{*}{ B2 } & \multicolumn{3}{|c|}{ Shale } & \multirow[b]{2}{*}{$\min$} & \multirow[b]{2}{*}{$\max$} \\
\hline & B3 & B4 & B5 & B7 & B9 & $\mathrm{B} 8$ & Ave & & & & & & & B6 & B10 & Ave & & \\
\hline $\mathrm{SiO}_{2}$ & 92.48 & 94.23 & 94.02 & 80.18 & 88.38 & 78.7 & 87.99 & 78.7 & 94.23 & 62.40 & 65.92 & 52.3 & 83.4 & 38.41 & 70.57 & 61.17 & 38.41 & 83.4 \\
\hline $\mathrm{Al}_{2} \mathrm{O}_{3}$ & 4.66 & 3.51 & 3.53 & 10.69 & 5.11 & 10.13 & 6.27 & 3.51 & 10.69 & 18.9 & 15.17 & 26.26 & 7.82 & 30.36 & 18.47 & 20.73 & 7.82 & 30.36 \\
\hline $\mathrm{Fe}_{2} \mathrm{O}_{3}$ & 0.31 & 0.21 & 0.26 & 1.76 & 3.6 & 4.14 & 1.71 & 0.21 & 4.14 & 7.18 & 5 & 3.58 & 1.58 & 8.09 & 0.99 & 3.56 & 0.99 & 8.09 \\
\hline $\mathrm{MgO}$ & 0.02 & 0.02 & 0.02 & 0.07 & 0.01 & 0.06 & 0.03 & 0.01 & 0.07 & 2.19 & 2.20 & 0.4 & 0.05 & 0.17 & 0.09 & 0.18 & 0.05 & 0.4 \\
\hline $\mathrm{CaO}$ & 0.08 & 0.06 & 0.22 & 0.02 & 0.05 & 0.03 & 0.08 & 0.02 & 0.22 & 1.29 & 4.19 & 0.05 & 0.03 & 0.02 & 0.02 & 0.03 & 0.02 & 0.05 \\
\hline $\mathrm{Na}_{2} \mathrm{O}$ & 0.18 & 0.11 & 0.18 & 0.03 & 0.12 & 0.06 & 0.11 & 0.03 & 0.18 & 1.19 & 3.9 & 0.02 & 0.04 & 0.01 & 0.03 & 0.025 & 0.01 & 0.04 \\
\hline $\mathrm{K}_{2} \mathrm{O}$ & 0.12 & 0.08 & 0.11 & 0.57 & 0.07 & 0.42 & 0.23 & 0.07 & 0.57 & 3.68 & 0.5 & 1.34 & 0.49 & 0.56 & 0.41 & 0.7 & 0.41 & 1.34 \\
\hline $\mathrm{TiO}_{2}$ & 0.44 & 0.32 & 0.24 & 1.53 & 0.42 & 1.49 & 0.74 & 0.24 & 1.53 & 0.99 & 0.76 & 1.71 & 1.14 & 0.98 & 1.54 & 1.34 & 0.98 & 1.71 \\
\hline $\mathrm{P}_{2} \mathrm{O}_{5}$ & 0.04 & 0.01 & 0.03 & 0.07 & 0.07 & 0.09 & 0.05 & 0.01 & 0.09 & 0.16 & 0.2 & 0.16 & 0.04 & 0.08 & 0.06 & 0.09 & 0.04 & 0.16 \\
\hline $\mathrm{MnO}$ & 0.01 & 0.01 & 0.01 & 0.01 & 0.01 & 0.01 & 0.01 & 0.01 & 0.01 & 0.11 & 0.07 & 0.01 & 0.01 & 0.02 & 0.01 & 0.01 & 0.01 & 0.02 \\
\hline $\mathrm{Cr}_{2} \mathrm{O}_{3}$ & 0.003 & 0.002 & 0.003 & 0.01 & 0.005 & 0.01 & 0.01 & 0.002 & 0.01 & & & 0.019 & 0.005 & 0.016 & 0.01 & 0.01 & 0.01 & 0.02 \\
\hline LOI & 1.50 & 1.30 & 1.30 & 4.60 & 2.10 & 4.40 & & & & & & 13.90 & 5.00 & 21.10 & 7.60 & & & \\
\hline $\mathrm{Al}_{2} \mathrm{O}_{3} / \mathrm{SiO}_{2}$ & 19.85 & 26.85 & 26.64 & 7.5005 & 17.30 & 7.77 & 17.65 & 7.50 & 26.85 & & & 1.99 & 10.66 & 1.27 & 3.82 & 4.44 & 1.27 & 10.66 \\
\hline $\mathrm{Al}_{2} \mathrm{O}_{3} / \mathrm{TiO}_{2}$ & 10.59 & 10.97 & 14.71 & 6.99 & 12.17 & 6.80 & 10.37 & 6.80 & 14.71 & & & 15.36 & 6.86 & 30.98 & 11.99 & 16.30 & 6.86 & 30.98 \\
\hline $\mathrm{SiO}_{2} / \mathrm{TiO}_{2}$ & 210.18 & 294.47 & 391.75 & 52.41 & 210.43 & 52.82 & 202.01 & 52.41 & 391.75 & & & 30.58 & 73.16 & 39.19 & 45.82 & 47.19 & 30.58 & 73.16 \\
\hline $\mathrm{K}_{2} \mathrm{O} / \mathrm{Na}_{2} \mathrm{O}$ & 0.67 & 0.73 & 0.61 & 19.00 & 0.58 & 7.00 & 4.76 & 0.58 & 19.00 & & & 67.00 & 12.25 & 56.00 & 13.67 & 37.23 & 12.25 & 67.00 \\
\hline $\mathrm{Al}+\mathrm{k}+\mathrm{Na}$ & 4.96 & 3.7 & 3.82 & 11.29 & 5.3 & 10.61 & 6.61 & 3.7 & 11.29 & & & 27.62 & 8.35 & 30.93 & 18.91 & 21.45 & 8.35 & 30.93 \\
\hline CIA & 92.46 & 93.35 & 87.38 & 94.52 & 95.51 & 95.21 & 93.07 & 87.38 & 95.51 & & & 94.90 & 93.32 & 98.09 & 97.57 & 95.97 & 93.32 & 98.09 \\
\hline CIW & 94.72 & 95.38 & 89.82 & 99.53 & 96.78 & 99.12 & 95.89 & 89.82 & 99.53 & & & 99.73 & 99.113 & 99.9 & 99.73 & 99.62 & 99.11 & 99.90 \\
\hline ICV & 0.25 & 0.23 & 0.29 & 0.37 & 0.84 & 0.61 & 0.43 & 0.23 & 0.84 & & & 0.27 & 0.43 & 0.32 & 0.17 & 0.30 & 0.17 & 0.43 \\
\hline
\end{tabular}

CIA: Chemical index of alteration, CIW, Chemical Index of Weathering, ICV: Index of compositional variability, UCC: average upper continental crust, PASS: Average Post Achaean Australian Shale, after [29] [30].

$\mathrm{Fe}_{2} \mathrm{O}_{3}$. All the analyzed samples show depletion in elemental oxides like $\mathrm{MgO}$, $\mathrm{Na}_{2} \mathrm{O}, \mathrm{K}_{2} \mathrm{O}$ and $\mathrm{TiO}_{2}$ with respect to the average UCC and PAAS values. $\mathrm{P}_{2} \mathrm{O}_{5}$ and $\mathrm{MnO}$ are strongly depleted in all the samples compared to average UCC and PAAS values. The depletion of the rocks in $\mathrm{K}_{2} \mathrm{O}, \mathrm{Na}_{2} \mathrm{O}$ and $\mathrm{CaO}$ does not only suggest quartz dilution but also implies that the sediments have suffered from chemical weathering at the source area [31] [32]. Feldspars exert primary control on the abundances of $\mathrm{Na}, \mathrm{K}$ and $\mathrm{Ca}$ in crystalline rocks and therefore strong depletion in $\mathrm{Na}_{2} \mathrm{O}, \mathrm{K}_{2} \mathrm{O}$ and $\mathrm{CaO}$ implies destruction of both plagioclase and $\mathrm{K}$-feldspars as a consequence of chemical weathering in the provenance or during sediment transport to basin. 
$\mathrm{SiO}_{2}$ concentration has a strong negative correlation with $\mathrm{Al}_{2} \mathrm{O}_{3}$ and $\mathrm{Fe}_{2} \mathrm{O}_{3}$ (Table 3), pointing to the fact that much of the $\mathrm{SiO}_{2}$ occurs either as detrital Table 2. Trace element concentrations ( $\mathrm{wt} \%$ ) of samples from Upper Maastrichtian Mamu Formation on the western flank of Anambra Basin.

\begin{tabular}{|c|c|c|c|c|c|c|c|c|c|c|c|c|c|c|c|c|c|c|}
\hline & & & & Sandstor & & & & & & & & & & & Shale & & & \\
\hline $\begin{array}{l}\text { Analyte } \\
\text { (ppm) }\end{array}$ & B3 & B4 & B5 & B7 & B9 & B8 & Ave & Min & $\operatorname{Max}$ & PASS & UCC & B1 & B2 & B6 & B10 & Ave & $\min$ & $\operatorname{Max}$ \\
\hline $\mathrm{Ba}$ & 47 & 26 & 38 & 148 & 34.00 & 133.00 & 71.00 & 26.00 & 148.00 & 650 & 550 & 189.00 & 106.00 & 115.00 & 127.00 & 134.25 & 106.00 & 189.00 \\
\hline $\mathrm{Cr}$ & 21 & 14 & 21 & 68 & 34 & 68 & 38 & 14 & 68 & 100 & 83 & 130 & 34 & 109 & 68 & 85 & 34 & 130 \\
\hline $\mathrm{Ni}$ & 20 & 20 & 20 & 20.00 & 20.00 & 20.00 & 20.00 & 20.00 & 20.00 & 55 & 44 & 20.00 & 44.00 & 20.00 & 20.00 & 26.00 & 20.00 & 44.00 \\
\hline $\mathrm{Sr}$ & 30 & 16 & 24 & 46.00 & 21.00 & 45.00 & 30.33 & 16.00 & 46.00 & 200 & 350 & 80.00 & 74.00 & 31.00 & 47.00 & 58.00 & 31.00 & 80.00 \\
\hline $\mathrm{Zr}$ & 604 & 278 & 154 & 2385.00 & 453.00 & 2717.00 & 1098.50 & 154.00 & 2717.00 & 210 & 190 & 428.00 & 82.00 & 2471.00 & 1171.00 & 1038.00 & 82.00 & 2471.00 \\
\hline $\mathrm{Y}$ & 11 & 10 & 6 & 75.00 & 10.00 & 87.00 & 33.17 & 6.00 & 87.00 & 27 & 22 & 63.00 & 39.00 & 43.00 & 53.00 & 49.50 & 39.00 & 63.00 \\
\hline $\mathrm{Nb}$ & 7 & 9 & 9 & 43.00 & 8.00 & 44.00 & 20.00 & 7.00 & 44.00 & 19 & 12 & 35.00 & 34.00 & 27.00 & 45.00 & 35.25 & 27.00 & 45.00 \\
\hline Sc & 2 & 2 & 2 & 11 & 3.00 & 11.00 & 5.17 & 2.00 & 11.00 & 16 & 13.6 & 21.00 & 17.00 & 6.00 & 14.00 & 14.50 & 6.00 & 21.00 \\
\hline $\mathrm{Sr} / \mathrm{Ba}$ & 1 & 0.62 & 0.63 & 0.31 & 0.62 & 0.34 & 0.43 & 0.62 & 0.31 & & & 0.42 & 0.70 & 0.27 & 0.37 & 0.43 & 0.29 & 0.42 \\
\hline
\end{tabular}

UCC: average upper continental crust, PASS: Average Post Achaean Australian Shale, after [29] [30].

Table 3. (a) correlation matrix of major and trace element concentration of sandstone samples from the study area; (b) correlation matrix of major and trace element concentration of shale samples from the study area.

(a)

\begin{tabular}{|c|c|c|c|c|c|c|c|c|c|c|c|c|c|c|c|c|c|c|}
\hline & $\mathrm{SiO}_{2}$ & $\mathrm{Al}_{2} \mathrm{O}_{3}$ & $\mathrm{Fe}_{2} \mathrm{O}_{3}$ & $\mathrm{MgO}$ & $\mathrm{CaO}$ & $\mathrm{Na}_{2} \mathrm{O}$ & $\mathrm{K}_{2} \mathrm{O}$ & $\mathrm{TiO}_{2}$ & $\mathrm{P}_{2} \mathrm{O}_{5}$ & $\mathrm{MnO}$ & $\mathrm{Cr}_{2} \mathrm{O}_{3}$ & $\mathrm{Ba}$ & $\mathrm{Ni}$ & $\mathrm{Sr}$ & $\mathrm{Zr}$ & $\mathrm{Y}$ & $\mathrm{Nb}$ & $\mathrm{Sc}$ \\
\hline $\mathrm{SiO}_{2}$ & 1.00 & & & & & & & & & & & & & & & & & \\
\hline $\mathrm{Al}_{2} \mathrm{O}_{3}$ & -0.98 & 1.00 & & & & & & & & & & & & & & & & \\
\hline $\mathrm{Fe}_{2} \mathrm{O}_{3}$ & -0.75 & 0.61 & 1.00 & & & & & & & & & & & & & & & \\
\hline $\mathrm{MgO}$ & -0.88 & 0.94 & 0.36 & 1.00 & & & & & & & & & & & & & & \\
\hline $\mathrm{CaO}$ & 0.64 & -0.63 & -0.54 & -0.48 & 1.00 & & & & & & & & & & & & & \\
\hline $\mathrm{Na}_{2} \mathrm{O}$ & 0.86 & -0.86 & -0.56 & -0.83 & 0.75 & 1.00 & & & & & & & & & & & & \\
\hline $\mathrm{K}_{2} \mathrm{O}$ & -0.90 & 0.96 & 0.39 & 0.99 & -0.50 & -0.84 & 1.00 & & & & & & & & & & & \\
\hline $\mathrm{TiO}_{2}$ & -0.97 & 0.82 & 0.57 & 0.97 & -0.62 & -0.87 & 0.97 & 1.00 & & & & & & & & & & \\
\hline $\mathrm{P}_{2} \mathrm{O}_{5}$ & -0.90 & 0.82 & 0.90 & 0.60 & -0.52 & -0.60 & 0.65 & 0.77 & 1.00 & & & & & & & & & \\
\hline \multicolumn{19}{|l|}{$\mathrm{MnO}$} \\
\hline $\mathrm{Cr}_{2} \mathrm{O}_{3}$ & -0.99 & 0.99 & 0.70 & 0.91 & -0.57 & -0.85 & 0.93 & 0.97 & 0.88 & & 1.00 & & & & & & & \\
\hline $\mathrm{Ba}$ & -0.94 & 0.98 & 0.48 & 0.98 & -0.52 & -0.82 & 0.99 & 0.99 & 0.73 & & 0.96 & 1.00 & & & & & & \\
\hline \multicolumn{19}{|l|}{$\mathrm{Ni}$} \\
\hline $\mathrm{Sr}$ & -0.89 & 0.94 & 0.45 & 0.93 & -0.43 & -0.66 & 0.94 & 0.94 & 0.75 & & 0.91 & 0.97 & & 1.00 & & & & \\
\hline $\mathrm{Zr}$ & -0.97 & 0.98 & 0.60 & 0.95 & -0.61 & -0.83 & 0.94 & 0.99 & 0.79 & & 0.96 & 0.98 & & 0.94 & 1.00 & & & \\
\hline $\mathrm{Y}$ & -0.96 & 0.97 & 0.59 & 0.96 & -0.57 & -0.85 & 0.94 & 0.99 & 0.76 & & 0.96 & 0.97 & & 0.93 & 1.00 & 1.00 & & \\
\hline $\mathrm{Nb}$ & -0.95 & 0.97 & 0.54 & 0.98 & -0.53 & -0.87 & 0.96 & 0.99 & 0.72 & & 0.96 & 0.98 & & 0.92 & 0.98 & 0.99 & 1.00 & \\
\hline $\mathrm{Sc}$ & -0.97 & 0.99 & 0.60 & 0.96 & -0.57 & -0.88 & 0.96 & 0.99 & 0.78 & & 0.98 & 0.98 & & 0.92 & 0.99 & 0.99 & 0.99 & 1.00 \\
\hline
\end{tabular}


(b)

\begin{tabular}{|c|c|c|c|c|c|c|c|c|c|c|c|c|c|c|c|c|c|c|}
\hline & $\mathrm{SiO}_{2}$ & $\mathrm{Al}_{2} \mathrm{O}_{3}$ & $\mathrm{Fe}_{2} \mathrm{O}_{3}$ & $\mathrm{MgO}$ & $\mathrm{CaO}$ & $\mathrm{Na}_{2} \mathrm{O}$ & $\mathrm{K}_{2} \mathrm{O}$ & $\mathrm{TiO}_{2}$ & $\mathrm{P}_{2} \mathrm{O}_{5}$ & $\mathrm{MnO}$ & $\mathrm{Cr}_{2} \mathrm{O}_{3}$ & $\mathrm{Ba}$ & $\mathrm{Ni}$ & $\mathrm{Sr}$ & $\mathrm{Zr}$ & Y & $\mathrm{Nb}$ & $\mathrm{Sc}$ \\
\hline $\mathrm{SiO}_{2}$ & 1.00 & & & & & & & & & & & & & & & & & \\
\hline $\mathrm{Al}_{2} \mathrm{O}_{3}$ & -0.98 & 1.00 & & & & & & & & & & & & & & & & \\
\hline $\mathrm{Fe}_{2} \mathrm{O}_{3}$ & -0.90 & 0.78 & 1.00 & & & & & & & & & & & & & & & \\
\hline $\mathrm{MgO}$ & -0.59 & 0.64 & 0.30 & 1.00 & & & & & & & & & & & & & & \\
\hline $\mathrm{CaO}$ & -0.05 & 0.09 & -0.14 & 0.81 & 1.00 & & & & & & & & & & & & & \\
\hline $\mathrm{Na}_{2} \mathrm{O}$ & 1.00 & -0.98 & -0.89 & -0.55 & 0.00 & 1.00 & & & & & & & & & & & & \\
\hline $\mathrm{K}_{2} \mathrm{O}$ & -0.39 & 0.43 & 0.13 & 0.97 & 0.94 & -0.34 & 1.00 & & & & & & & & & & & \\
\hline $\mathrm{TiO}_{2}$ & 0.12 & 0.07 & -0.53 & 0.58 & 0.62 & 0.12 & 0.62 & 1.00 & & & & & & & & & & \\
\hline $\mathrm{P}_{2} \mathrm{O}_{5}$ & -0.57 & 0.64 & 0.26 & 1.00 & 0.81 & -0.54 & 0.96 & 0.63 & 1.00 & & & & & & & & & \\
\hline $\mathrm{MnO}$ & -0.77 & 0.65 & 0.94 & -0.03 & -0.47 & -0.77 & -0.22 & -0.71 & -0.06 & 1.00 & & & & & & & & \\
\hline $\mathrm{Cr}_{2} \mathrm{O}_{3}$ & -0.88 & 0.93 & 0.62 & 0.89 & 0.45 & -0.87 & 0.74 & 0.34 & 0.88 & 0.37 & 1.00 & & & & & & & \\
\hline $\mathrm{Ba}$ & -0.15 & 0.26 & -0.19 & 0.88 & 0.91 & -0.12 & 0.93 & 0.86 & 0.89 & -0.50 & 0.60 & 1.00 & & & & & & \\
\hline $\mathrm{Ni}$ & -0.77 & 0.65 & 0.94 & -0.03 & -0.47 & -0.77 & -0.22 & -0.71 & -0.06 & 1.00 & 0.37 & -0.50 & 1.00 & & & & & \\
\hline $\mathrm{Sr}$ & -0.92 & 0.95 & 0.70 & 0.85 & 0.40 & -0.91 & 0.70 & 0.24 & 0.84 & 0.46 & 0.99 & 0.52 & 0.46 & 1.00 & & & & \\
\hline $\mathrm{Zr}$ & 0.96 & -1.00 & -0.74 & -0.65 & -0.09 & 0.97 & -0.44 & -0.13 & -0.65 & -0.60 & -0.93 & -0.29 & -0.60 & -0.94 & 1.00 & & & \\
\hline Y & 0.01 & 0.15 & -0.42 & 0.71 & 0.75 & 0.02 & 0.75 & 0.98 & 0.75 & -0.65 & 0.45 & 0.94 & -0.65 & 0.36 & -0.21 & 1.00 & & \\
\hline $\mathrm{Nb}$ & -0.14 & 0.32 & -0.20 & 0.04 & -0.29 & -0.19 & -0.11 & 0.52 & 0.10 & -0.11 & 0.23 & 0.13 & -0.11 & 0.18 & -0.39 & 0.41 & 1.00 & \\
\hline $\mathrm{Sc}$ & -0.82 & 0.90 & 0.48 & 0.86 & 0.41 & -0.81 & 0.70 & 0.48 & 0.87 & 0.26 & 0.97 & 0.63 & 0.26 & 0.95 & -0.92 & 0.56 & 0.43 & 1.00 \\
\hline
\end{tabular}

quartz grains or cement. The ratio of $\mathrm{SiO}_{2} / \mathrm{Al}_{2} \mathrm{O}_{3}$ is highly variable ranging from 7.50 to 26.85 and it shows high silica to alumina content. The $\mathrm{K}_{2} \mathrm{O} / \mathrm{Al}_{2} \mathrm{O}_{3}$ ratio in the sandstones is low (0.01-0.05) and it is an indication of low concentration of $\mathrm{K}$-bearing minerals relative to alumina bearing ones. The concentration of $\mathrm{Al}_{2} \mathrm{O}_{3}$ in the samples shows strong positive correlation with $\mathrm{Fe}_{2} \mathrm{O}_{3}, \mathrm{MgO}, \mathrm{K}_{2} \mathrm{O}, \mathrm{TiO}_{2}$, and $\mathrm{P}_{2} \mathrm{O}_{5}(\mathrm{r}=0.61,0.94,0.96,0.82$ and 0.82 respectively) but shows very strong negative correlation with $\mathrm{Na}_{2} \mathrm{O}$ and $\mathrm{CaO}(\mathrm{r}=-0.63$ and -0.98$)$. The association of $\mathrm{Al}_{2} \mathrm{O}_{3}$ with oxides $\mathrm{Fe}_{2} \mathrm{O}_{3}, \mathrm{~K}_{2} \mathrm{O}, \mathrm{TiO}_{2}, \mathrm{P}_{2} \mathrm{O}_{3}$ suggests their derivation from aluminosilicates [31].

The analyzed samples are classified based on the geochemical classification scheme proposed by Herron [33]. The bivariate plot of $\log \left(\mathrm{Fe}_{2} \mathrm{O}_{3} / \mathrm{K}_{2} \mathrm{O}\right)$ versus $\log \left(\mathrm{SiO}_{2} / \mathrm{Al}_{2} \mathrm{O}_{3}\right)$ has proven to be a useful discriminant tool for the classification of clastic sedimentary rocks on the basis of their major element composition. The shale samples were classified mainly as Fe-shale and shale, while the sandstone samples fell in sub-litharenite, litharenite and Fe-sandstone fields (Figure 4). According to this scheme, sandstone sample from the study area are predominantly litharenites and sublitharenites, which suggests that they are chemically immature. This deduction is however negated by the high $\mathrm{SiO}_{2}$ and CIA values. 


\subsection{Trace Elements}

An overview of some trace element concentration and elemental ratios are presented in Table 2. The shales samples have higher concentration of $\mathrm{Ba}, \mathrm{Ni}, \mathrm{Sr}, \mathrm{Y}$, $\mathrm{Nb}$, Sc. (average 134, 25, 58, 49.50, 35.25, and $14.50 \mathrm{ppm}$ ) in comparison to sandstones samples (71, 20, 30.33, 33.17, 20 and 5.17). However, sandstone samples have higher concentration in $\mathrm{Zr}(1098.50 \mathrm{ppm})$ than the shales (1038 ppm). Shale and sandstones samples are highly depleted in Ba (71 and $134 \mathrm{ppm})$ relative to the average UCC and PAAS values (550 and $650 \mathrm{ppm}$ ).All the samples are enriched in $\mathrm{Zr}$ in comparison to average UCC and PAAS. suggesting the presence of heavy mineral zircon. $\mathrm{Zr}$ is an ultra-stable heavy mineral and will survive the rigor of weathering, and diagenesis. Average concentration of $\mathrm{Sr}$ in shale and sandstones (30.33 and $58.00 \mathrm{ppm}$ ) are significantly lower than their averages in UCC and PAAS (350.0 and $200 \mathrm{ppm}$ ). Ni has the same average concentration value of $20 \mathrm{ppm}$ as that of UCC for sandstone samples, however, it is depleted when compared to the average PAAS concentration ( $55 \mathrm{ppm})$. on the other hand, the average concentration $\mathrm{Ni}$ in shales ( $26 \mathrm{ppm}$ ) is higher than the average UCC ( $20 \mathrm{ppm}$ ) but lower than the average PAAS value of $55 \mathrm{ppm}$. Average concentrations of $\mathrm{Y}, \mathrm{Nb}$ in both shales (49.50, $20 \mathrm{ppm}$ ) and sandstone (33.17, 35.25 ppm) sample are higher than the average PAAS $(27,19 \mathrm{ppm})$ and UCC $(22,12$ $\mathrm{ppm}$ ) values. meaning both shale and sandstone samples are enriched in $\mathrm{Y}$ and $\mathrm{Nb}$. The sandstone samples are depleted in Sc compared to average PAAS (16 $\mathrm{ppm})$ and UCC (13.6 ppm) values, whereas, the shale samples are slightly enriched in Sc in comparison to average UCC (13.6 ppm) but slightly depleted compared to average PAAS value of $14.50 \mathrm{ppm}$. One of the major characteristics of the trace elements distribution is the generally strong positive correlation of $\mathrm{Ni} \mathrm{Sr}$ and Sc with $\mathrm{A}_{2} \mathrm{O}_{3}$ indicating that these elements are associated with aluminosilicates. $\mathrm{Ba}, \mathrm{Y}$ and $\mathrm{Nb}$ show very weak positive correlation with $\mathrm{Al}_{2} \mathrm{O}_{3}$ while $\mathrm{Zr}$ concentration indicates very strong negative correlation. On the other hand, $\mathrm{Zr}$ abundances show strong positive correlation with $\mathrm{SiO}_{2}$ (Table 3). This is because $\mathrm{Zr}$ is associated with zircon, an ultrastable heavy mineral that usually get concentrated with detrital quartz. In a similar vein, $\mathrm{Sr}, \mathrm{Ni}$ and $\mathrm{Sc}$ show strong or moderate positive correlation with $\mathrm{Fe}_{2} \mathrm{O}_{3}$ while $\mathrm{Zr}$ show strong negative correlation. $\mathrm{Ba}, \mathrm{Y}$ and $\mathrm{Nb}$ display weak negative correlation with $\mathrm{Fe}_{2} \mathrm{O}_{3}$.

\section{Discussion of Results}

\subsection{Chemical Composition}

The chemical composition of siliciclastic sedimentary rocks is controlled by numerous factors such as weathering, sediment transport and depositional environment. The most essential of these factors include 1) composition of parents rocks, 2) grain size sorting effect during sediment transport and deposition [34], 3) chemical weathering during the entire sedimentary process and outcrop exposure [36], and 4) burial diagenesis and metamorphism [35]. According to Jian et al. [14], it is necessary to evaluate the effects of the last three factors of chemi- 
cal composition of sediments before drawing conclusion on provenance, paleoclimate and tectonic setting of the depositional basin.

Hydrodynamic sorting of detrital particles on the bases of density, grain size and particle shape during sediment transport and deposition results in mineralogical heterogeneity and consequently chemical differentiation. The effect of grain size arising from hydrodynamic sorting can be easily observed on the geochemical data presented in Table 1 and Table 2. The sandstones have more $\mathrm{SiO}_{2}$ contents but less $\mathrm{Al}_{2} \mathrm{O}_{3} \mathrm{Fe}_{2} \mathrm{O}_{3}$ and $\mathrm{TiO}_{2}$ than the associated mudrocks. $\mathrm{SiO}_{2}$ concentrations increase with increasing grain size as a result of quartz enrichment while $\mathrm{Al}_{2} \mathrm{O}_{3}$ concentration increases with decreasing grain size because fine-grained sediments are enriched in clay minerals. According to Ben-Awuah et al. [37], grain size differences is the result of hydrodynamic sorting during sediment transport and deposition leading to coarser grained sediments being generally richer in $\mathrm{SiO}_{2}$ and $\mathrm{K}_{2} \mathrm{O}$ (wt\%) contents as a result of their higher quartz and feldspar contents compared to finer grained ones. Compositional differences in the studied samples are manifest in the 4 various classes depicted by the geochemical classification scheme of Herron [33]. The plot identified the sandstones as Fe-sandstone, sublitharenites and litharenites while the mudrocks are designated as Fe-shale, shale and sublitharenites (Figure 4). This separation of samples into different classes is the result of variation in grain size with medium- or coarse-grained sediments designated mainly as litharenite, sublitharenites and Fe sandstone while fine grained sediments are mainly shale or Fe-shale and sublitharenite. The analyzed sediments indicate moderate chemical maturity because of the absence of sample in quartz arenite field.

Furthermore, the geochemistry of major elements of sandstone samples suggests that they are strongly depleted in $\mathrm{K}_{2} \mathrm{O}, \mathrm{Na}_{2} \mathrm{O}$, and $\mathrm{CaO}$, but shows quite

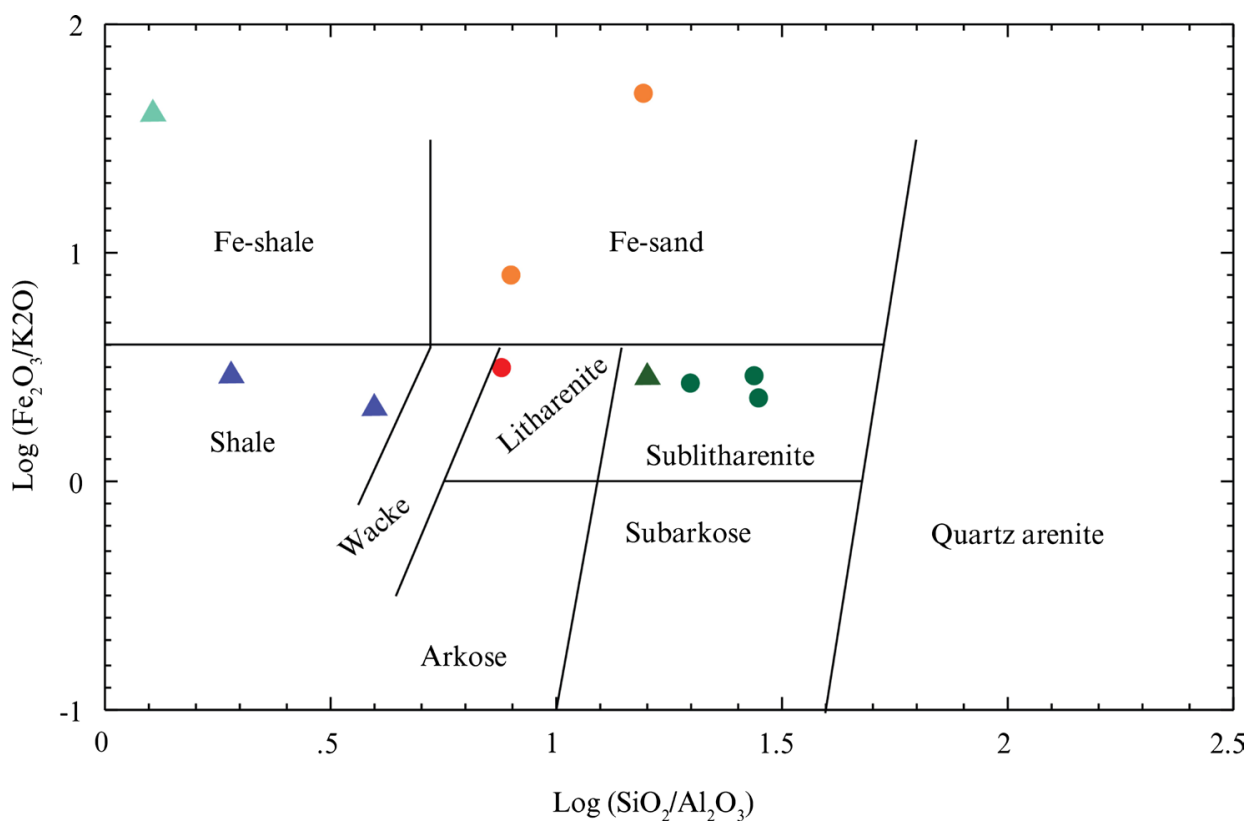

Figure 4. Chemical classification of sediments from the study area, fields after [33]. 
significant enrichment in $\mathrm{SiO}_{2}, \mathrm{Al}_{2} \mathrm{O}_{3}, \mathrm{TiO}_{2}$ and $\mathrm{Fe}_{2} \mathrm{O}_{3}$. This trend can be attributed to the high mobility character exhibited by $\mathrm{K}^{+}, \mathrm{Na}^{+}$, and $\mathrm{Ca}^{2+}$ ions in humid climatic setting. They tend to leach easily in contrast to the immobile $\mathrm{Ti}^{2+}$ and $\mathrm{Al}^{3+}$ ions, since the latter have high resistance to erosion. $\mathrm{SiO}_{2} / \mathrm{Al}_{2} \mathrm{O}_{3}$ ratio increases with grain size and it is an indicator chemical maturity of the sandstones. $\mathrm{SiO}_{2}$ is resistant to chemical weathering. According to Bhatia, [38], $\mathrm{Al}_{2} \mathrm{O}_{3}$ is a common member of mature residual product of weathering as a result of its immobility.

Cox et al. [39] demonstrated how the present chemical composition can be used to deduce the original detrital mineralogy of shale samples. One way of achieving this is to use the index of chemical variability, ICV $=\left(\mathrm{Fe}_{2} \mathrm{O}_{3}+\mathrm{k}_{2} \mathrm{O}+\right.$ $\left.\mathrm{Na}_{2} \mathrm{O}+\mathrm{CaO}+\mathrm{MgO}+\mathrm{TiO}_{2}\right): \mathrm{Al}_{2} \mathrm{O}_{3}$ ) and the ratio of $\mathrm{K}_{2} \mathrm{O}: \mathrm{Al}_{2} \mathrm{O}_{3}$. According to Cox et al. [39] and Culler and Podkovyrov [40] non-clay minerals have a higher ratio of the major cations to $\mathrm{Al}_{2} \mathrm{O}_{3}$ than clay minerals and so the non-clay minerals have a higher ICV. They stated that ICV decreases in the order of pyroxene and amphibole (c. 10 - 100), biotite (c. 8), alkali feldspar (c. 0.8 - 1), plagioclase (c. 0.6), muscovite and illite (c. 0.3), montmorillionite (c. 0.15 - 0.3), and kaolinite (c. 0.03 - 0.05). Cox et al. [39] and Culler and Podkovyrov [40] further stated that immature shales, which are typical of first cycle deposits in tectonically active settings, have a high percent of non-clay silicate minerals and therefore contain ICV values of greater than one while more mature mudrocks with mostly clay minerals have lower ICV values of less than one. The average ICV of the analyzed shale samples is 0.30 (range $0.17-0.43$ ), suggesting the original shales contained dominantly muscovite and clay minerals and is compositionally mature and may have been recycled. The ICV values also suggest deposition of sediments in passive margin tectonic settings.

In addition, $\mathrm{K}_{2} \mathrm{O} / \mathrm{Al}_{2} \mathrm{O}_{3}$ ratios may indicate how much alkali feldspar vs. plagioclase and clay minerals may have been present in the original shales [39]. In decreasing order of values, the $\mathrm{K}_{2} \mathrm{O}: \mathrm{Al}_{2} \mathrm{O}_{3}$ ratios of minerals are alkali feldspars (0.4 - 1), illite (0.3), other clay minerals (roughly 0) [39] [40]. According to Cox et al. [39] and Culler Culler and Podkovyrov [40], shales with ratios of $\mathrm{K}_{2} \mathrm{O}: \mathrm{Al}_{2} \mathrm{O}_{3}$ greater than 0.5 suggest a significant quantity of alkali feldspar relative to other minerals in the original shale; those with ratios of $\mathrm{K}_{2} \mathrm{O}: \mathrm{Al}_{2} \mathrm{O}_{3}$ less than 0.4 suggest minimal alkali feldspar in the original shale. The $\mathrm{K}_{2} \mathrm{O}: \mathrm{Al}_{2} \mathrm{O}_{3}$ values of samples for the present study are generally low both for the sandstones $(0.00-0.05)$ and shales $(0.00-0.01)$, suggesting the presence of insignificant amount of alkali feldspar in the original sediments.

\subsection{Provenance}

The composition of sediments is typical of certain assemblages of igneous, metamorphic and sedimentary provenances that have unique style of sedimentary history [34]. Some major and trace elements are considered to be very useful for constraining the composition of provenance and tectonic setting as a result of 
their immobile nature during weathering and transport and their short residence time in saline water [29]. Since these elements are thought to fractionate only a little during continental erosion, they are distributed proportionately into clastic sediments, thereby reflecting the chemical signature of the parent materials [29] [41]. Two commonly used provenance discrimination diagrams are those of [12] and [42]. Roser and Korsh [12] introduced two major elements discriminant function diagrams to constrain provenances and compositions of source rocks. The first diagram is best suited for sediments containing little or no biogenic fraction while the second one is adapted for sediments with significant biogenic content. The diagrams differentiated four types of source rocks: 1) Mafic igneous (basaltic and subordinate andesitic detritus), 2) intermediate igneous (dominantly andesitic detritus) 3) Felsic (acidic plutonic and volcanic detritus), and 4) quartzose sedimentary (recycled detritus). Samples for this study contain no significant biogenic content based on geochemical signature of very low $\mathrm{CaO}$ concentration and judging from megascopic examination of samples. Plots on the relevant provenance diagram of [12] indicates that majority of the samples fall well within the quartzose sedimentary provenance field with only one sample falling in the felsic igneous field, suggesting tectonic uplift and sedimentary recycling (Figure 5). The spread of the samples may result from compositional variations in the protoliths. This result suggests a significant contribution from recycled detritus or intensive sediment reworking. Recycled sedimentary provenance interpretation is in conformity with the consensus claim by some authors in the basin, [e.g. [4] [18]] that recycled sediment from the Abakaliki anticline located E of the study area was the major source of terrigenous input to the Santonian Anambra Basin. The provenance indicated by [12] discriminant diagram is however different from the one depicted by [42]. Hayashi et al. [42] employed bivariate plot of $\mathrm{TiO}_{2}$ against $\mathrm{Al}_{2} \mathrm{O}_{3}$ to discriminate among four provenance types: basalt, basalt-granite, granite-basalt and granite sources. The plot shows that half of the samples (five) fell in the granite field, two in the granite-basalt field, two in the basalt-granite field and one in an undefined field (Figure 6). They also employed bivariate plot of $\mathrm{TiO}_{2}$ vs. $\mathrm{Zr}$ to discriminate three provenance types: mafic igneous, intermediate igneous and felsic igneous rock provenances. Provenance interpretations from $\mathrm{TiO}_{2}$ and $\mathrm{Zr}$ ratios is premised on the fact that these elements $\mathrm{Ti}$ and $\mathrm{Zr}$ ) are associated with some of the most stable heavy minerals (rutile and Zircon) in siliciclastic rocks and are therefore thought to preserve the geochemical signatures of the parent rocks [37] [43]. This diagram (Figure 7) indicates that most of the analyzed samples fall in the felsic igneous field with only one sample falling in the intermediate igneous rock field, indicating a provenance consisting dominantly of felsic igneous rocks with minor contribution from intermediate igneous rocks. A comparison of the sample distributions in the two [42] provenance schemes indicates that there are no significant differences in outcomes if it is assumed that their basalt-granite and granite-basalt fields are equivalent to intermediate igneous field except for one 
sample with an undefined provenance. It is however difficult to decide the provenance of the sample that fell in the undefined field. Hayashi et al. [42] failed to recognize quartzose sedimentary (recycled detritus) provenance.

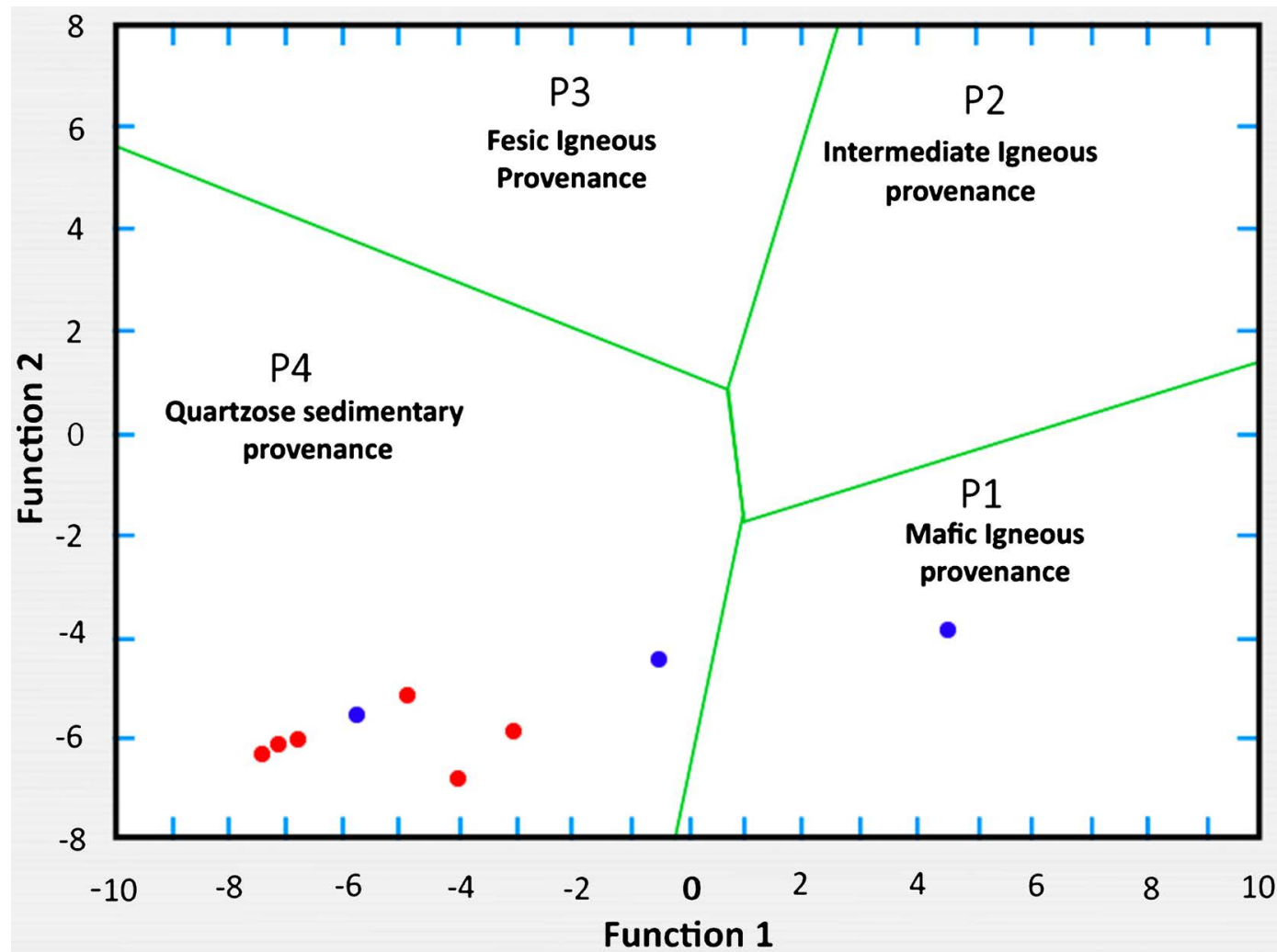

Figure 5. Discriminant function diagram for provenance signatures of sandstone-shale samples from the study area using major elements, fields after [12].

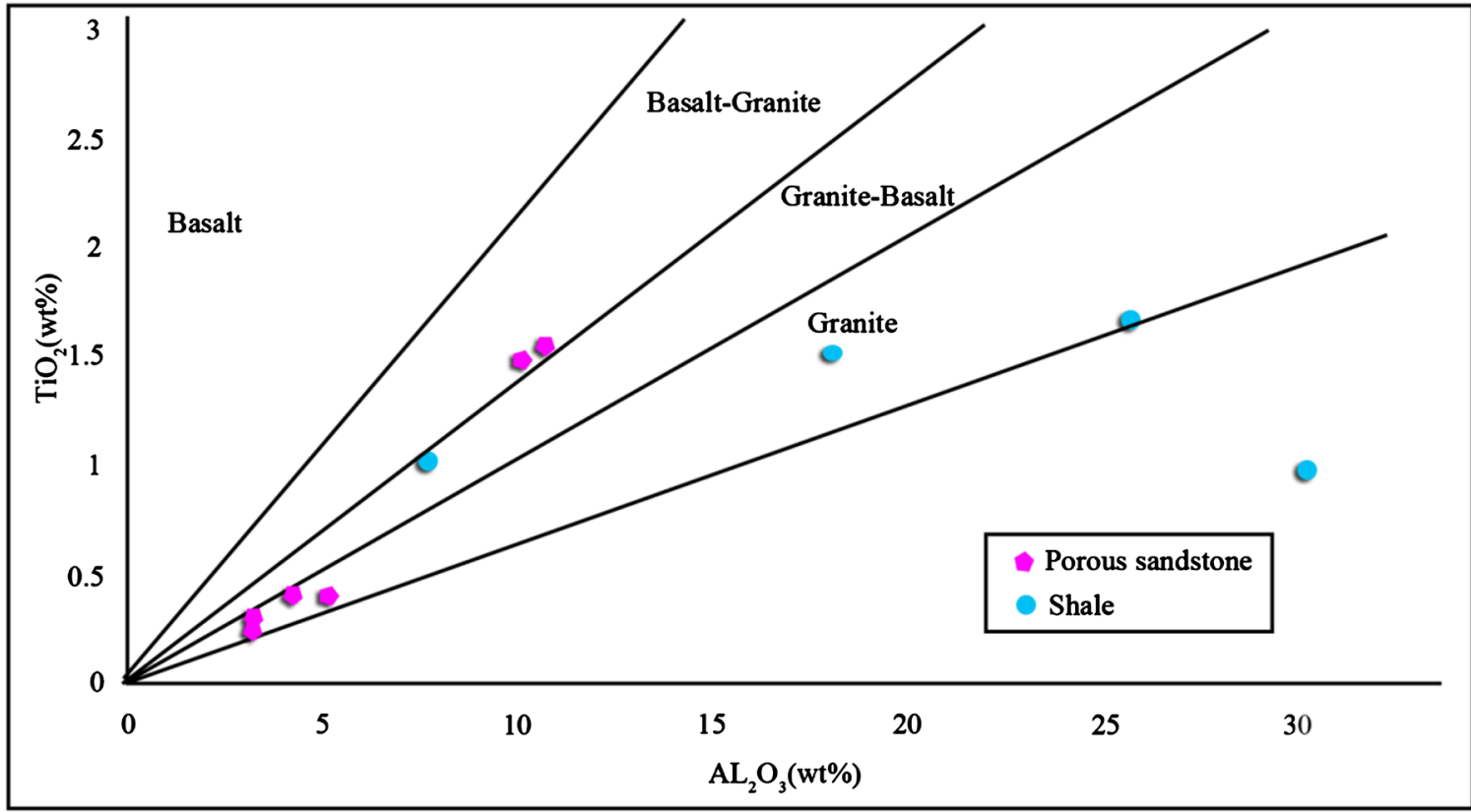

Figure 6. Scatter diagram of $\mathrm{Al}_{2} \mathrm{O}_{3}$ vs. $\mathrm{TiO}_{2}$ for the analyzed samples, fields after [42]. 


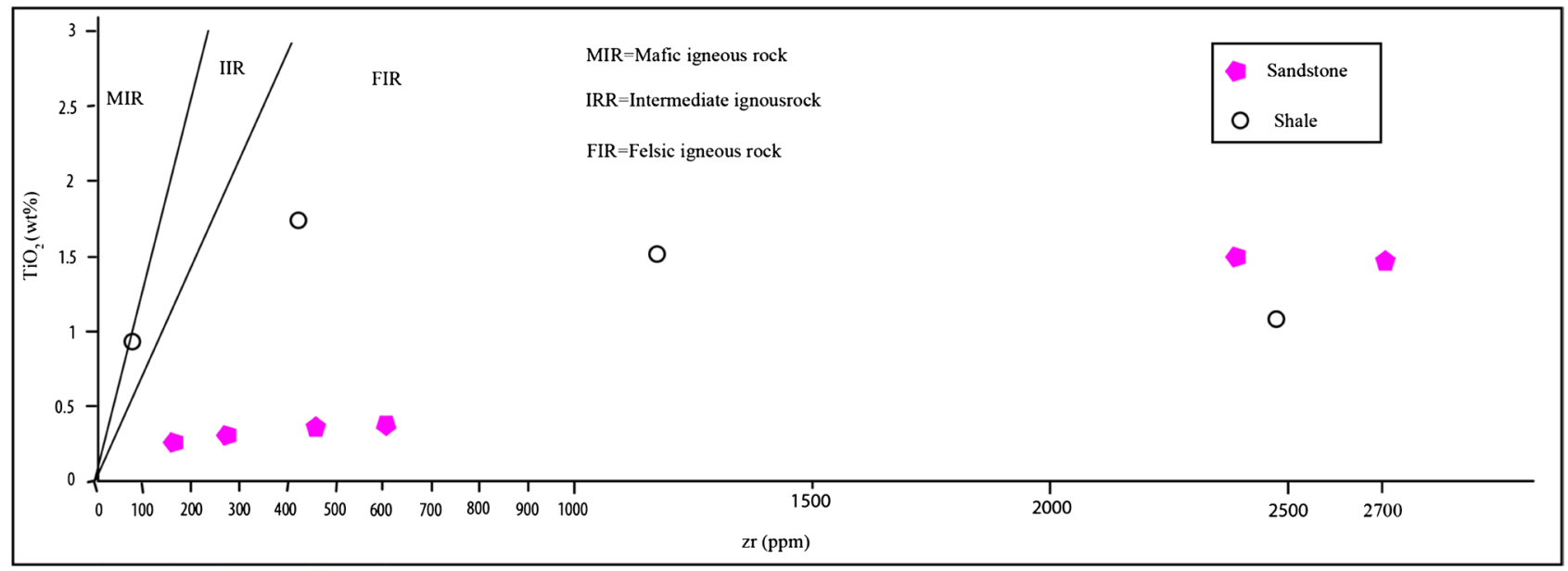

Figure 7. Scatter diagram of $\mathrm{TiO}_{2}$ vs. $\mathrm{Zr}$ for the analyzed samples, fields after [42].

Trace elements especially high field strength elements (e.g. Y and Zr) and ferrromagnisian elements (e.g. $\mathrm{Ni}, \mathrm{Cr}$ and $\mathrm{Sc}$ ) also can be used as proxy for provenance because they are relatively immobile and undergo/experience little/minimal fractionation during weathering and erosion. The concentration of $\mathrm{Y}$ is higher in argillaceous rocks than in sandstones. All the samples are relatively enriched in Y compared to the UCC and PAAS. The abundances of $\mathrm{Zr}$ in the samples are highly variable in both argillaceous and siliceous sediments. On the average, both sandstones and shales samples are enrichment in $\mathrm{Zr}$ compared to the UCC and PAAS. The high variations in the concentration of $\mathrm{Zr}$ among samples may result from hydraulic sorting during sediment transport. Zirconium (Zr) content of detrital sedimentary rocks is much associated with ultrastable heavy mineral $\mathrm{Zircon}\left(\mathrm{ZrSiO}_{4}\right)$ which is very resistant to both mechanical disintegration and chemical decomposition. Consequently, it is enriched in the detritus compared to the parent material. The high concentration of $\mathrm{Zr}$ suggests felsic igneous, and/or quartzose sedimentary provenance since felsic igneous rocks are relatively enriched in $\mathrm{Zr}$ compared to mafic igneous rocks.

Moreover, the deduced of felsic igneous and/or quartzose sedimentary provenance for the sediment from study area is corroborated by low concentrations of $\mathrm{Cr}, \mathrm{Ni}, \mathrm{Sc}$. Sc, $\mathrm{Cr}$ and $\mathrm{Ni}$ are preferentially partitioned into mafic igneous rock during fractional crystallization of silicate melt such that late stage crystallization products such as granite and pegmatite contain low concentration of these elements. According to Cullers and Podkovyro [40], $\mathrm{Sc}, \mathrm{Ni}, \mathrm{Cr}$ are usually concentrated in basic igneous rocks. Therefore, the depletion of these elements in the studied samples suggests either sediment derivation from felsic igneous rocks or that mafic lithologies played insignificant role.

\subsection{Tectonic Setting}

Deductions on the tectonic setting of the depositional basin can be made by evaluating the geochemical signatures of the sediments. Different chemical characteristics are displayed by sediments deposited in different tectonic settings. 
According to [[13], p. 576] and [37], the $\mathrm{K}_{2} \mathrm{O} / \mathrm{Na}_{2} \mathrm{O}$ ratios and $\mathrm{SiO}_{2}$ content of siliciclastic sedimentary rocks are particularly sensitive indicators of geotectonic setting and this formed the basis of Roser and Korsch [44] tectonic setting discriminant diagram. Roser and Korsch [44] used the plot $\mathrm{K}_{2} \mathrm{O} / \mathrm{Na}_{2} \mathrm{O}$ against $\mathrm{SiO}_{2}$ to discriminant among samples from three main tectonic settings namely ocean island arc margin (ARC, active continental margin (ACM), and passive margin (PM). The samples plot both in passive margin (60\%) and active continental margin (40\%) regions (Figure 8). This result is consistent with the low to high $\mathrm{K}_{2} \mathrm{O} / \mathrm{Na}_{2} \mathrm{O}$ values $(0.58$ - 30.93). According to [44], sediments originating from passive margin have high $\mathrm{K}_{2} \mathrm{O} / \mathrm{Na}_{2} \mathrm{O}$ ratios while sediments from $\mathrm{ACM}$ have low values. This result should however be treated with caution because of the influence of grain size variations arising from hydraulic sorting during sediment transport exacts on chemical composition. Generally, sediment becomes enriched in stable mineral phases such quartz with concomitant depletion in labile minerals such as feldspar as tectonic setting changes from oceanic island arc to active continental margin to passive margin, resulting in increasing $\mathrm{SiO}_{2}$ concentrations and increasing $\mathrm{K}_{2} \mathrm{O} / \mathrm{Na}_{2} \mathrm{O}$ ratios [38] [44].

Verma and Armstrong-Altrin [45] recently proposed two discriminant function diagrams based on major elements for the tectonic discrimination of high silica and low silica sediments. These diagrams are comprised of three major different tectonic setting regions namely continental arc (island arc), continental rift and collision. Samples for the present study are comprised of eight high silica

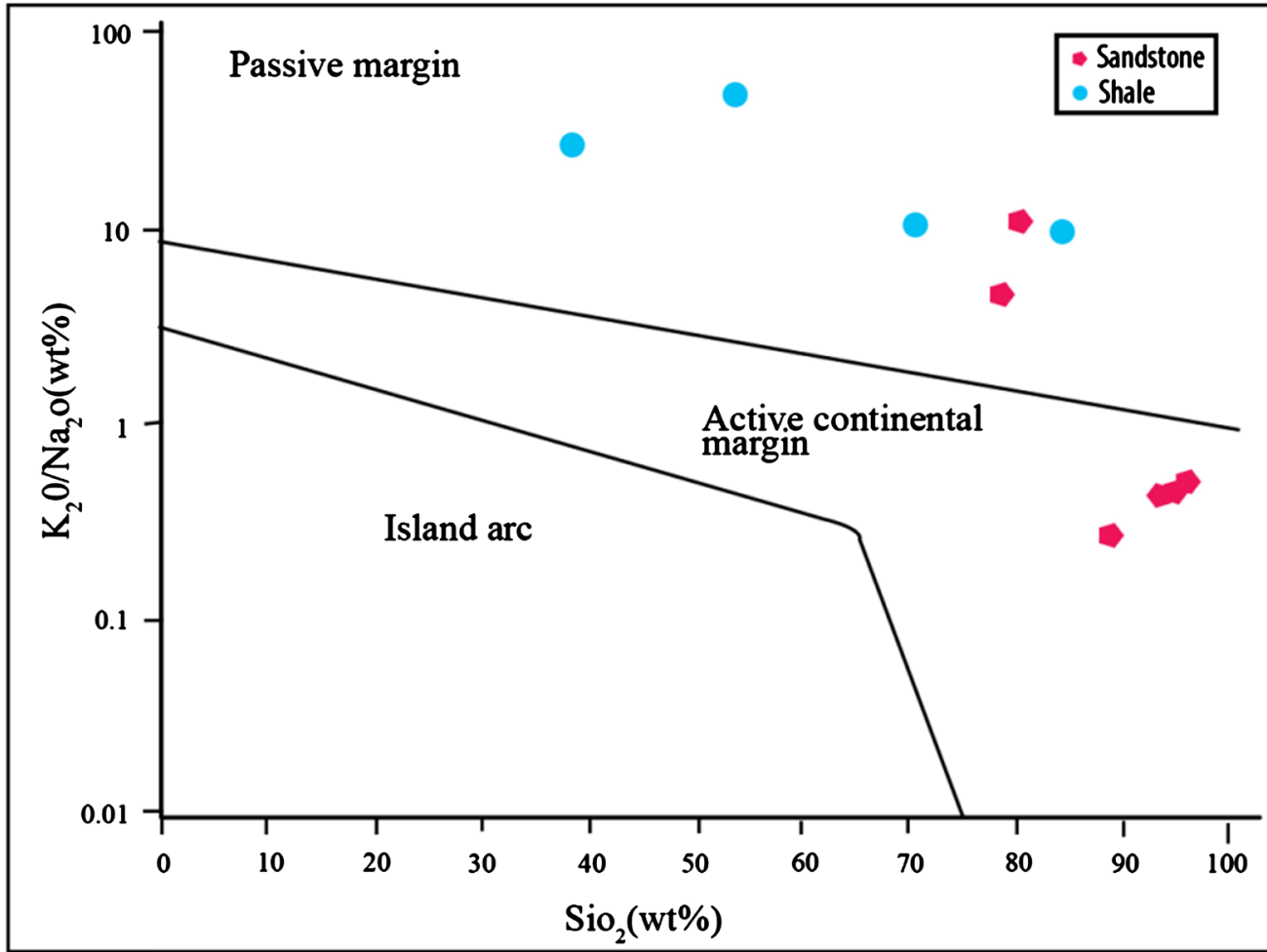

Figure 8. Tectonic discriminant diagram of $\mathrm{SiO}_{2}$ vs. $\mathrm{K}_{2} \mathrm{O} / \mathrm{Na}_{2} \mathrm{O}$ scatter plot for analyzed samples, fields after [44]. 
and two low silica types. The discriminant functions diagrams of [45] have been used to constrain the tectonic setting of the sediments of the study area (Figure 9). All silica-rich samples plotted in the continental rift region. One of the two low silica samples plotted in the continental rift field while the other one plotted in collision region of [45] diagram. We prefer the result of the tectonic setting depicted in [45] diagrams because their diagrams have been proven to have higher success rate compared to that of [44]. Their diagrams were able to successfully discriminate among sediments collected from different known tectonic settings at success rate of $84.5 \%$ to $93.6 \%$ whereas the former diagram recorded a maximum success rate of $62 \%$ which is considered unsatisfactory [45]. Therefore the analyzed samples from the study area were deposited mainly in continental rift/ passive margin setting.

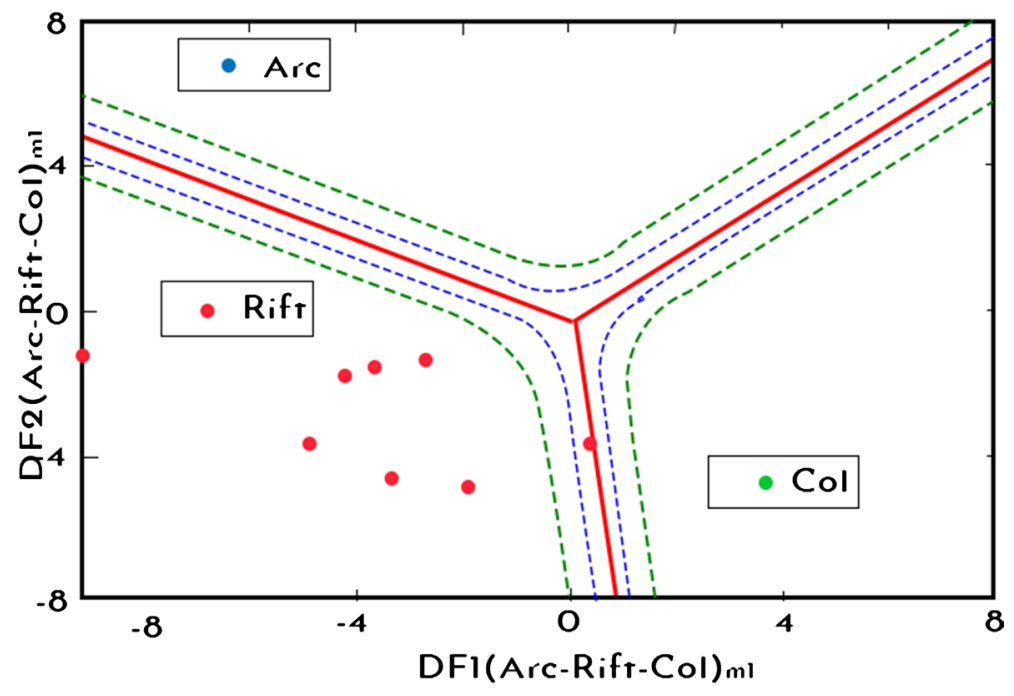

S.P. Verma, J.S. Armstrong-Altrin 2013

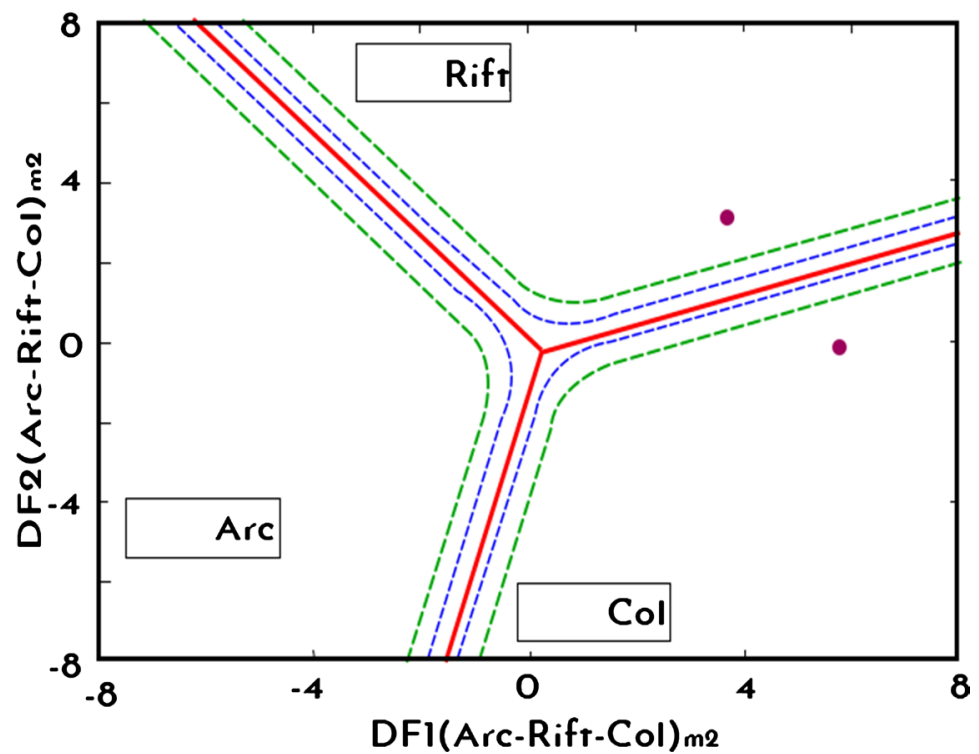

Figure 9. Tectonic setting discriminant function plots for high silica (top) and low-silica (bottom) samples, fields after [45]. 


\subsection{Source Area Weathering and Paleoclimate}

The effect of chemical weathering on the composition of siliciclastic sedimentary rocks can be evaluated by measuring the degree of chemical weathering. Various weathering indices are available in literature but the most commonly used ones are the chemical index of alteration, CIA; [36] and chemical index of weathering, CIW; [46]. The CIA monitors the gradual conversion of feldspars to clay minerals. The applicability of this index is premised on the fact that feldspars are the most abundant minerals of the upper continental crust and that the major process involved in chemical weathering is the alteration of feldspars to form clay minerals [30] [47]. The index was calculated using molar proportion in the equation $\left[\mathrm{CIA}=\mathrm{Al}_{2} \mathrm{O}_{3} /\left(\mathrm{CaO}^{*}+\mathrm{Na}_{2} \mathrm{O}+\mathrm{K}_{2} \mathrm{O}\right]\right.$, where $\mathrm{CaO}^{*}$ is the concentration of $\mathrm{CaO}$ occurring in the silicate minerals (adjusted for $\mathrm{CaO}$ in carbonates and phosphates). Even though the petrographic investigation was not undertaken, the low concentration of $\mathrm{CaO}$ and the low LOI values (Table 1) suggest that the $\mathrm{CaO}$ in the samples are associated silicate with silicate phases. The CIA index values of analyzed sandstones (range 87.38 - 95.51; average, 93.07) and shales (range 93.32 - 98.09; average 95.97) samples from the study area (Table 1) are high and clearly indicate intense or deep chemical weathering at the source area in a humid climatic condition. It should be noted that the associated shale samples have a higher CIA values compared to the sandstones. This is probably reflecting the effect of grain sorting. Sandstones contained mainly quartz grains and little clay matrix $\left(\mathrm{Al}_{2} \mathrm{O}_{3}\right)$ since much of the fine clay particles were winnowed away to be redeposited further downstream with muds during sediment transport and deposition and thus can greatly affect the CIAs of sandstones.

Nesbitt and Young [36] applied CIA index to the study of fine-grained sediments only and not sandstones because the composition of mudrocks is thought to be more similar to that of the parent rocks compared to coarse-grained clastic sediments [30]. According to [36] [47] and [35], CIA values of 50 to 60 indicate low weathering; CIA values of 60 - 80 indicates intermediate weathering; CIA values of $80-100$ reflects extreme weathering. The CIA of unaltered feldspar is 50. According to [35], CIA of 100 indicates complete conversion of feldspar to aluminous clay minerals such as kaolinite [47]. Chemical weathering is relevant only under humid condition resulting in substantial leaching of mobile cations $\left(\mathrm{Na}^{+}, \mathrm{K}^{+}\right.$and $\left.\mathrm{Ca}^{2+}\right)$ and a concomitant enrichment of $\mathrm{Si}$ and $\mathrm{Al}$ in the residuum. Climate and rate of tectonic uplift are the main factors controlling the degree of chemical weathering. According to [48] and [49], increased intensity of chemical weathering may suggest decrease in tectonic activity and/or change of climate towards warm and humid climatic conditions which are more favorable for chemical weathering in the source region. In arid or cool condition, sediment is produced primarily by abrasion and attrition which involve mere physical disintegration of the parent materials with insignificant chemical alterations. Also, the degree of chemical weathering was evaluated using chemical index of weathering (CIW). The use of the CIA index should be treated with caution since it 
was founded on restrictive assumptions which may, in some instances present a challenging obstacle to its practical applicability [50]. The usability of CIA is based on the assumptions that the initial geochemistry of the unweathered parent rock is invariant and that $\mathrm{Al}_{2} \mathrm{O}_{3}, \mathrm{CaO}, \mathrm{K}_{2} \mathrm{O}$ and $\mathrm{Na}_{2} \mathrm{O}$ resides exclusively in feldspars. Therefore, if significant quantity of other minerals (e.g. amphibole, pyroxene) that also contain these elements are present in the parent rock, the application of the CIA becomes unreliable [50].

As noted by [46], the unpredictable character of $\mathrm{K}^{+}$during weathering can be a source of error in CIA since [36] assumed $\mathrm{K}_{2} \mathrm{O}$ to be a mobile component. According to [46], $\mathrm{K}^{+}$can be used in the formation of $\mathrm{K}$-minerals or adsorbed onto other clay minerals through ion exchange even after entering solution. This informed the calculation of chemical index of weathering. $\mathrm{CIW}=\left[\mathrm{Al}_{2} \mathrm{O}_{3} /\left(\mathrm{Al}_{2} \mathrm{O}_{3}+\right.\right.$ $\mathrm{Na}_{2} \mathrm{O}+\mathrm{CaO}$ ) $] \times 100$. The CIW values of analyzed samples (Table 1 ) range from 89.82 - 99.53 (ave 95.89) and 99.11 - 99.90 (ave 99.62) for sandstones and shale samples respectively. The CIW values are higher for shales than sandstones and mimic the pattern of CIA. The high CIW values (close to 100) for the analyzed samples reflect intense chemical of the sauce area. The CIW index increases with the degree of depletion of $\mathrm{Na}$ and $\mathrm{Ca}$ in sediments, relative to $\mathrm{Al}$ [46]. According to [46], the difference between the CIW index values for the parent rock and the sediment indicates the amount of chemical weathering experienced by the weathered material.

Although CIA and CIW indices can be used to determine the degree of source area weathering of sediment, they however cannot be used to deduce the trends of paleo-weathering conditions, especially in sediments with variable provenances because they are mere numerical values. Therefore the CIA was incorporated into $\mathrm{A}\left(\mathrm{Al}_{2} \mathrm{O}_{3}\right)-\mathrm{CN}\left(\mathrm{CaO}^{*}+\mathrm{Na}_{2} \mathrm{O}\right)-\mathrm{K}\left(\mathrm{K}_{2} \mathrm{O}\right)$ compositional diagram which can effectively evaluate chemical weathering, diagenesis, metamorphism and source composition of clastic sediments [35]. The concentrations of A-CN-K in moles of samples from the study area were plotted on a ternary A-CN-K diagram to determine the trend of chemical weathering, composition of parent materials and the likely effect of metasomatism (Figure 10). The plot indicates a tight cluster of data-points very close to the $\mathrm{Al}_{2} \mathrm{O}_{3}$ apex and oriented roughly parallel to the A-CN join suggesting substantial loss of $\mathrm{Ca}, \mathrm{Na}$ and $\mathrm{K}$ in the parent material and abundance of mineral phases with compositions close to kaolinite, smectite and illite in the samples. The observed trend that roughly paralleled the A-CN join suggests that potassium metasomatism played insignificant role in the sedimentary process. According to Nesbitt and Young [47], the interpretation of the paleo-weathering trends in sediments can be used to deduce the climatic regimes influencing the composition of sediments. The occurrence of kaolinite in terrigenous sediments indicates tropical weathering conditions (Nesbitt and Young, 1982) Following the method proposed by [51] the composition of the parent materials was established by drawing a line of best fit through the data points and projecting it backwards to the Plagioclase-potassium 


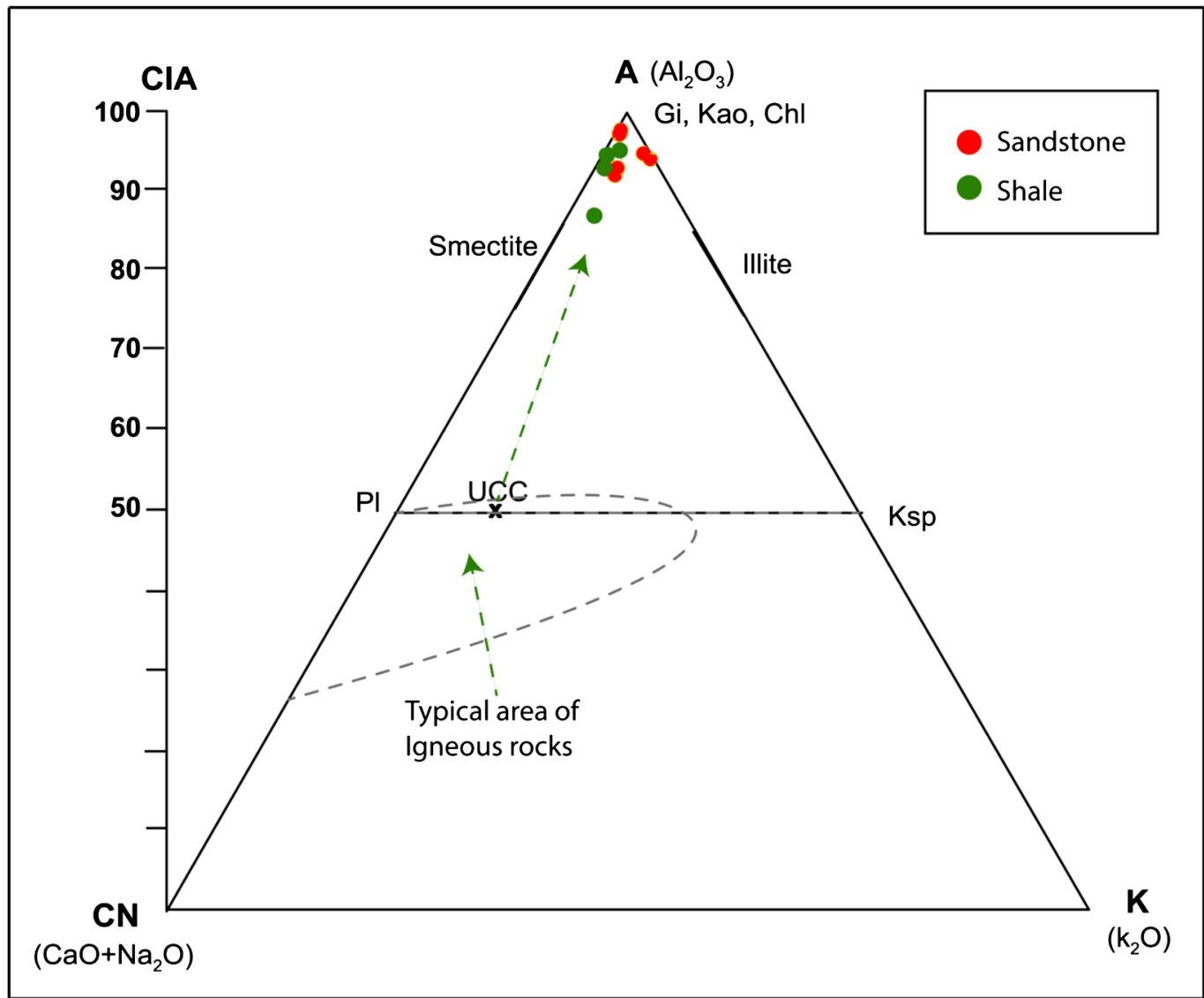

Figure 10. Distribution of analyzed samples in the A-CN-K $\left(\mathrm{Al}_{2} \mathrm{O}_{3}-\mathrm{CaO}+\mathrm{Na}_{2} \mathrm{O}-\mathrm{K}_{2} \mathrm{O}\right)$ ternary diagram, modified after [36] with calculated CIA values. Dashed line illustrates weathering trend, Pl (plagioclase feldspar), Ksp (K-feldspar), Gi (gibbsite), Kao (kaolinite), Ch (chlorite).

feldspar join. The point of intersection suggests that the K-feldspar/plagioclase ratio in the parent material is close to $2: 5$, suggesting the dominance of granite and/or granodiorite in the source area. Granite and granodiorite can be traced to the crystalline Basement Complex rocks of northern Nigeria [52]. Also, the position of the samples on the A-CN-K diagram (close to kaolinite) together with their corresponding high CIA index values suggests that the sediments were produced from a source area strongly affected by intense chemical weathering which resulted in selective depletion of mobile elements (e.g. Ca, Na, K) and preferential enrichment of $\mathrm{Al}$ and $\mathrm{Si}$ in the weathering profiles [53]. Also, the low abundances of $\mathrm{CaO}, \mathrm{K}_{2} \mathrm{O}$ and $\mathrm{Na}_{2} \mathrm{O}$ in geochemical data (Table 1 ) is typical of a humid environment, because of their high degree of mobility.

\subsection{Maturity}

The bivariate plot of $\mathrm{SiO}_{2}$ against total $\mathrm{Al}_{2} \mathrm{O}_{3}+\mathrm{K}_{2} \mathrm{O}+\mathrm{Na}_{2} \mathrm{O}$ (Figure 11) proposed by [54] was employed to determine the climatic conditions at the provenance and chemical maturity of the sediments (Figure 10). The plot depicts a humid to semi-humid conditions for the sandstones, but an arid climatic setting for the shale samples. The plot also indicates that the samples from the study area are 


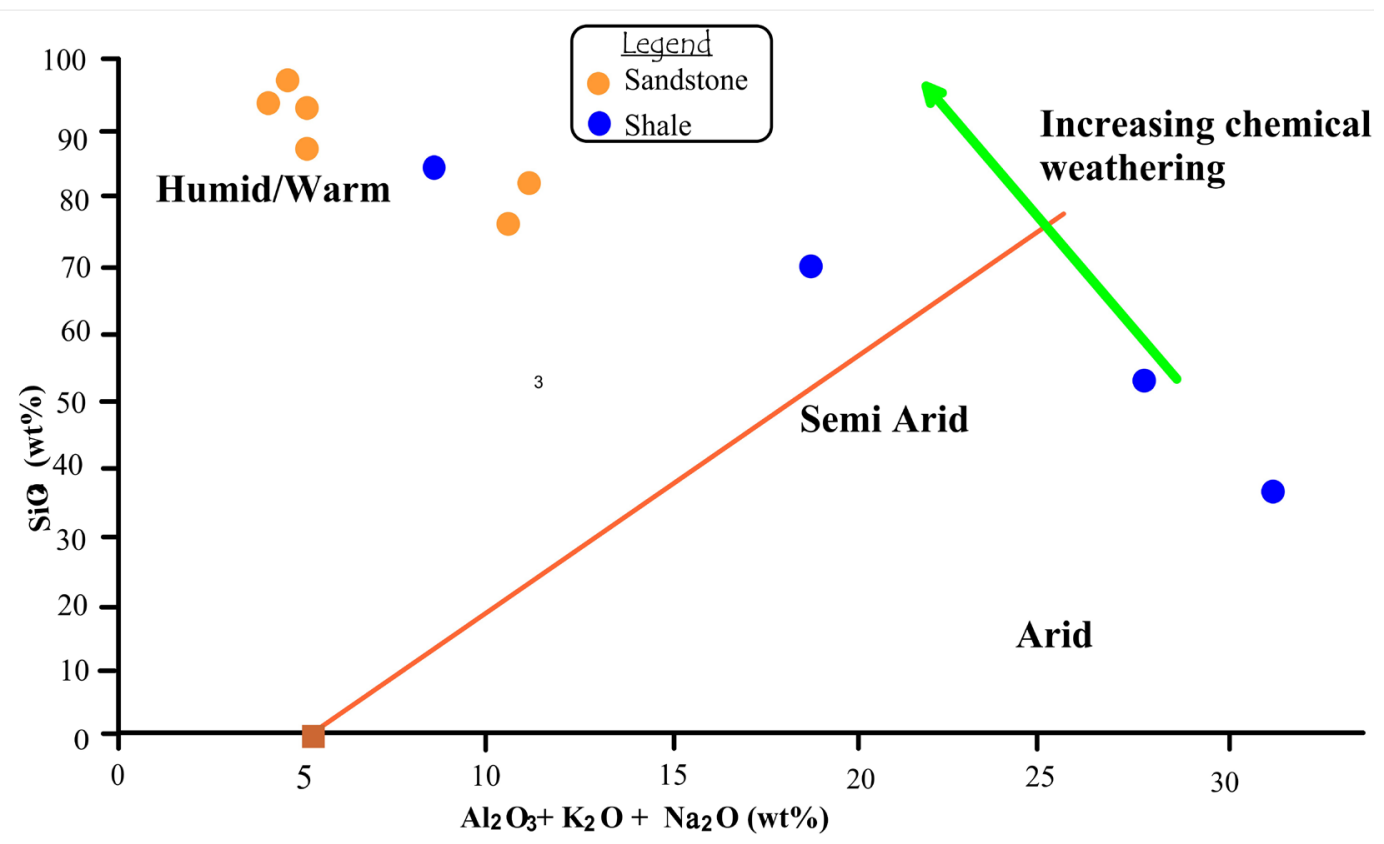

Figure 11. Paleoclimate discrimination diagram of samples from the study area using bivariant plot, fields after [54].

chemically mature, which is corroborated by the high CIW and CIA values and deduction on A-CN-K ternary plot. The high silica content observed from geochemical analysis of the samples suggests either their sourcing from highly siliceous rocks or intense reworking of pre-existing siliciclastic sediments. Highly siliceous sediments are product of geochemically stable minerals that formed under relatively cold and hydrous conditions which enable them develop crystal structure that are chemically and mechanically stable at surface atmospheric conditions. They readily adjust to the relatively cold and wet sedimentary environment. High level of compositional maturity of the sediments is further corroborated by their low ICV values $(0.17-0.43)$. Mature clastic sediments are usually the product of multiple recycling of or reworking of weathering materials leading to complete decomposition of labile component as feldspars on a stable passive margin setting under humid and wet tropical climatic condition [40]. Consequently, the detritus is enriched in stable mineral phase as quartz.

\subsection{Depositional Paleoenvironment}

Schmitz et al. [55] stated that both $\mathrm{Sr}$ and $\mathrm{Ba}$ are sensitive to variations of paleo-salinity, and they are more concentrated in seawater than fresh water. They however noted that difference in sedimentary environments could separate their correlations. Barium (Ba) is easily precipitated as $\mathrm{BaSO}_{4}$ while $\mathrm{Sr}$ can migrate further because of its higher solubility than that of $\mathrm{Ba}$ [56]. Thus, the $\mathrm{Sr} / \mathrm{Ba}$ ratio is commonly used to estimate the changes of paleoenvironments of sedimentary rocks [57]. $\mathrm{Sr} / \mathrm{Ba}>1$ indicates marine deposition whereas $\mathrm{Sr} / \mathrm{Ba}<1$ indicates continental deposition [57]. The $\mathrm{Sr} / \mathrm{Ba}$ ratios of the sandstones and shales sam- 
ples in the current study is in the range of 0.31 to 0.64 with an average value of 0.53 , and 0.27 to 0.70 with an average of 0.44 suggesting deposition in a continental or deltaic setting. Inferred continental or delta depositional paleoenvironment is in agreement with the work of [24] who reported that the sediments of Maatrichtian Mamu Formation were deposited in a wide range of paleoenvironments including fluvial, deltaic, distributary channel, estuarine, shoreface, tidal flats and swamp.

\section{Conclusion}

Geochemical analysis of clastic rocks of Maastrichtian Mamu Formation from western flank of Anambra Basin has been carried out. Geochemical classification of sandstone samples indicated that they were mainly litharenites, sublitharenites and Fe sandstones, while the shale samples are classified mainly as Fe-shale and shale. The rocks are depleted in $\mathrm{K}_{2} \mathrm{O}, \mathrm{Na}_{2} \mathrm{O}$, and $\mathrm{CaO}$, with corresponding enrichment in $\mathrm{SiO}_{2}, \mathrm{Al}_{2} \mathrm{O}_{3}, \mathrm{TiO}_{2}$ and $\mathrm{Fe}_{2} \mathrm{O}_{3}$. The high $\mathrm{SiO}_{2}$ values indicated that the sediment was derived from highly siliceous rocks or intense reworking of pre-existing siliciclastic sediment. Provenance interpretations as indicated by scatter plots of $\mathrm{TiO}_{2}$ vs. $\mathrm{Zr}$ and $\mathrm{TiO}_{2}$ vs $\mathrm{Al}_{2} \mathrm{O}_{3}$ together with deductions from the A-CN-K diagram suggests that sediments were derived mainly from felsic igneous rocks with minor input from intermediate igneous and quartzose sedimentary terrain. Inference suggested that the parent materials consisted of granite and granodiorite and were located in Basement complex areas of northern Nigeria and Oban massif. The sediments from the study area was deposited in a continental or deltaic environment on a passive margin setting that probably experienced tectonic uplift at some point in the history of the basin. The sediments were subjected to prolonged or intense chemical weathering at source terrain characterized by a semi arid to tropical paleo-climatic conditions and thus suggesting high chemical maturity for the samples.

\section{Conflicts of Interest}

The authors declare no conflicts of interest regarding the publication of this paper.

\section{References}

[1] Nwajide, C.S. and Reijers, T.J.A. (1996) Geology of the Southern Anambra Basin. In: Reijers, T.J.A., Ed., Selected Chapters on Geology, Warri, SPDC 1996, 133-148.

[2] Agagu, O.K., Fayose, E.A. and Petters, S.W. (1985) Stratigraphy and Sedimentation in the Senonian Anambra Basin of Eastern Nigeria. Nigerian Journal of Mining and Geology, 22, 377-385.

[3] Ekweozor, C.M. and Gomly, J.R. (1983) Petroleum Geochemistry Penetrated by the Akukwa-2 Well in the Anambra Basin, Southern Nigeria. Journal of Petroleum Geology, 6, 207-216. https://doi.org/10.1111/j.1747-5457.1983.tb00417.x

[4] Unomah, G.I. and Ekweozor, C.M. (1993) Application of Vitrinite Reflectance in Reconstruction of Tectonic Features in Anambra Basin, Nigeria: Implication for 
Petroleum Potential. AAPG Bulletin, 77, 136-151.

[5] Akande, S.O., Ogunmoyero, I.B., Petersen, H.I. and Nytoft, H.P. (2007) Source Rock Evaluation of Coals from the Lower Maastrichtian Mamu Formation, SE Nigeria. Journal of Petroleum Geology, 30, 303-324. https://doi.org/10.1111/j.1747-5457.2007.00303.x

[6] Ojo, O.J., Kolawole, A.U. and Akande, S.O. (2009) Depositional Environments, Organic Richness, and Petroleum Generating Potential of the Campanian to Maastrichtian Enugu Formation, Anambra Basin, Nigeria. The Pacific Journal of Science and Technology, 10, 614-628.

[7] Akande, S.O., Adeoye, M.O. and Erdtmann, B.D. (2015) Petroleum Source Rock Potential Assessment of the Oligocene-Miocene Ogwashi Asaba Formation, Southern Anambra Basin, Nigeria. Petroleum Technology Development Journal, 5, 4-34.

[8] Adekoya, J.A., Aluko, A.F. and Opeloye, S.A. (2011) Sedimentological Characteristics of Ajali Sandstone in the Auchi Environs of Anambra Basin, Nigeria. Ife Journal of Science, 13, 52-67.

[9] Nton1, M.E. and Bankole, S.A. (2013) Sedimentological Characteristics, Provenance and Hydrocarbon Potential of Post Santonian Sediments in Anambra Basin, Southeastern Nigeria. $R M Z-M \& G, 60,47-66$.

[10] Eynatten, H.V., Barceló-Vidal, C. and Glahn, V.P. (2003) Composition and Discrimination of Sandstones: A Statistical Evaluation of Different Analytical Methods. Journal of Sedimentary Research, 73, 47-57. https://doi.org/10.1306/070102730047

[11] Blatt, H. (1985) Provenance Studies and Mudrocks. Journal of Sedimentary Petrology, 55, 69-75.

[12] Roser, B.P. and Korsch, R.J. (1988) Provenance Signature of Sandstone-Mudrock Suites Determined Using Discriminant Function Analysis of Major-Element Data. Chemical Geology, 67, 119-139. https://doi.org/10.1016/0009-2541(88)90010-1

[13] Boggs Jr., S. (2006) Principles of Sedimentology and Stratigraphy. 4th Edition, Prentice Hall, Upper Saddle River, 662.

[14] Jian, X., Guan, P., Zhang, W. and Feng, F. (2013) Geochemistry of Mesozoic and Cenozoic Sediments in the Northern Qaidam Basin, Northeastern Tibetan Plateau: Implications for Provenance and Weathering. Chemical Geology, 360-361, 74-88. https://doi.org/10.1016/j.chemgeo.2013.10.011

[15] Herron, S.L. and Herron, M.M. (1996) Quantitative Lithology: An Application for Open and Cased Hole Spectroscopy. Transactions of the SPWLA 37 th Annual Logging Symposium, New Orleans, 16-19 June 1996, Paper E14.

[16] Benkhelil, J. (1989) The Evolution of the Cretaceous Benue Trough, Nigeria. Journal of African Earth Sciences, 8, 251-282. https://doi.org/10.1016/S0899-5362(89)80028-4

[17] Nwajide, C.S. (2013) Geology of Nigeria's Sedimentary Basins. CSS Bookshops Limited, Lagos, 548.

[18] Hoque, M. (1977) Petrographic Differentiation of Tectonically Controlled Cretaceous Sedimentary Cycles, Southeastern Nigeria. Sedimentary Geology, 17, 235-245. https://doi.org/10.1016/0037-0738(77)90047-1

[19] Zaborski, P.M. (2000) The Cretaceous and Paleocene Transgressions in Nigeria and Niger. Journal of Mining and Geology, 36, 153-173.

[20] Reijers, T.J.A., Petters, S.W. and Nwajide, C.S. (1997) The Niger Delta Basin. In: Selley, R.C., Ed., African Basins, Sedimentary Basins of the World, Elsevier, Amsterdam, 3, 145-168. 
[21] Reijers, T.J.A. and Nwajide, C.S. (1998) Geology of the Southern Anambra Basin. Unpublished Report for Chevron Nigeria Limited, Field Course Note, 66.

[22] Akaegbobi, M.I. and Schmitt, M. (1998) Organic Facies, Hydrocarbon Source Potentials and Reconstruction of the Depositional Paleoenvironment of the Campano-Maastrichtian Nkporo Shale in the Cretaceous Anambra Basin, Nigeria. Nigerian Association of Petroleum Explorationists Bulletin, 13, 1-19.

[23] Agumanu, A.E. (1989) The Abakaliki and Ebonyi Formations: Subdivision of the Albian Asu River Group in the Southern Benue Trough, Nigeria. Journal of African Earth Sciences, 9, 195-207. https://doi.org/10.1016/0899-5362(89)90021-3

[24] Adeniran, B.V. (1991) Maastrichtian Tidal Flat Sequences from the Northern Anambra Basin, Southern Nigeria. Nigerian Association of Petroleum Explorationists Bulletin, 6, 56-66.

[25] Umeji, O.P. and Nwajide, C.S. (2007) Age Control and Designation of the Standard Stratotype of Nsukka Formation of Anambra Basin, Southeastern Nigeria. Journal of Mining and Geology, 43, 147-166.

[26] Odundun, O.A. (2015) Use of Geochemical Fossils as Indicators of Thermal Maturation: An Example from the Anambra Basin, Southeastern Nigeria. Journal of Geochemistry, 2015, Article ID: 809780. https://doi.org/10.1155/2015/809780

[27] Adegoke, O.S. (1969) Eocene Stratigraphy of Southern Nigeria. Collogue sur Eocene Vol. III Bur. Rech. Geol. Min. Mem., 69, 23-48.

[28] Oboh-Ikuenobe-F, E., Jean, M. and Lohmann G.P. (2005) Lithofacies, Palynofacies. and Sequence Stratigraphy of Paleogene Strata in Southeastern Nigeria. Journal of African Earth Sciences, 41, 79-101. https://doi.org/10.1016/j.jafrearsci.2005.02.002

[29] Taylor, S.R. and McLennan, S.M. (1985) The Continental Crust: Its Composition and Evolution. Blackwell, Oxford, $312 \mathrm{p}$.

[30] McLennan, S.M. (2001) Relationships between the Trace Element Composition of Sedimentary Rocks and Upper Continental Crust. Geochemistry Geophysics Geosystems, 2, 2000GC000109. https://doi.org/10.1029/2000GC000109

[31] Jin, Z., Fuchun. L., Cao, J., Wang, S. and Yu, J. (2006) Geochemistry of Daihai Lake Sediments, Inner Mongolia, North China: Implications for Provenance, Sedimentary Sorting and Catchment Weathering. Geomorphology, 80, 147-163. https://doi.org/10.1016/j.geomorph.2006.02.006

[32] Akarish, A.I.M. and El-Gohary, A.M. (2011) Provenance and Source Area Weathering Derived from Geochemistry of Precambrian Sandstones, East Sinai, Egypt. Journal of Applied Sciences, 11, 3070-3088. https://doi.org/10.3923/jas.2011.3070.3088

[33] Herron, M.M. (1988) Geochemical Classification of Terrigenous Sands and Shales from Core or Log Data. Journal of Sedimentary Petrology, 58, 820-829.

[34] McLennan, S.M. (1993) Weathering and Global Denudation. Journal of Geology, 101, 295-303. https://doi.org/10.1086/648222

[35] Fedo. C.M., Nesbitt, H.W. and Young, G.M. (1995) Unraveling the Effects of Potassium Metasomatism in Sedimentary Rocks and Paleosols, with Implications for $\mathrm{Pa}$ leoweathering Conditions and Provenance. Geology, 23, 921-924. https://doi.org/10.1130/0091-7613(1995)023<0921:UTEOPM>2.3.CO;2

[36] Nesbitt, H.W. and Young, G.M. (1982) Early Proterozoic Climates and Plate Motions Inferred from Major Chemistry of Lutites. Nature, 229, 715-717. https://doi.org/10.1038/299715a0

[37] Ben-Awuah, J., Padmanabhan1, E. and Sokkalingam, R. (2017) Geochemistry of 
Miocene Sedimentary Rocks from Offshore West Baram Delta, Sarawak Basin, Malaysia, South China Sea: Implications for Weathering, Provenance, Tectonic Setting, Paleoclimate and Paleoenvironment of Deposition. Geosciences Journal, 21, 167-185. https://doi.org/10.1007/s12303-016-0056-3

[38] Bhatia, M.R. (1983) Plate Tectonics and Geochemical Composition of Sandstones. Journal of Geology, 91, 611-627. https://doi.org/10.1086/628815

[39] Cox, R., Low, D.R. and Cullers, R.L. (1995) The Influence of Sediment Recycling and Basement Composition on Evolution of Mudrock Chemistry in the South-Western United States. Geochimica et Cosmochimica Acta, 59, 2919-2940. https://doi.org/10.1016/0016-7037(95)00185-9

[40] Cullers, R.L. and Podkovyrov, V.N. (2000) Geochemistry of the Mesoproterozoic Lakhanda Shales in Southeastern Yakutia, Russia: Implications for Mineralogical and Provenance Control, and Recycling. Precambrian Research, 104, 77-93. https://doi.org/10.1016/S0301-9268(00)00090-5

[41] Bhatia, M.R. and Crook, K.A.W. (1986) Trace Element Characteristics of Greywackes and Tectonic Setting Discrimination of Sedimentary Basins. Contributionsto Mineralogy and Petrology, 92, 181-193. https://doi.org/10.1007/BF00375292

[42] Hayashi, K., Fujisawa, H., Holland, H. and Ohmoto, H. (1997) Geochemistry of 1.9 Ga Sedimentary Rocksfrom Northeastern Labrador, Canada. Geochimicaet Cosmochimica Acta, 61, 4115-4137. https://doi.org/10.1016/S0016-7037(97)00214-7

[43] Morton, A.C. (1985) Heavy Minerals in Provenance Studies. In: Zuffa, G.G., Ed., Provenance of Arenites, Reidel, Dordrecht, 249-277. https://doi.org/10.1007/978-94-017-2809-6_12

[44] Roser, B.P. and Korsch, R.J. (1986) Determination of Tectonic Setting of Sandstone-Mudstone Suites Using $\mathrm{SiO}_{2}$ Content and $\mathrm{K}_{2} \mathrm{O} / \mathrm{Na}_{2} \mathrm{O}$ Ratio. Journal of Geology, 94, 635-650. https://doi.org/10.1086/629071

[45] Verma S.P. and Armstrong-Altrin, J.S. (2013) New Multi-Dimensional Diagrams for Tectonic Discrimination of Siliciclastic Sediments and Their Application to Precambrian Basins. Chemical Geology, 355, 117-133. https://doi.org/10.1016/j.chemgeo.2013.07.014

[46] Harnois, L. (1988) The CIW Index: A New Chemical Index of Weathering. Sedimentary Geology, 55, 319-322. https://doi.org/10.1016/0037-0738(88)90137-6

[47] Nesbitt, H.W. and Young, G.M. (1984) Prediction of Some Weathering Trends of Plutonic and Volcanic Rocks Based on Thermodynamic and Kinetic Considerations. Geochimica et Cosmochimica Acta, 48, 1523-1534. https://doi.org/10.1016/0016-7037(84)90408-3

[48] Jacobson, A.D., Blum, J.D., Chamberlian, C.P., Craw, D. and Koons, P.O. (2003) Climate and Tectonic Controls on Chemical Weathering in the New Zealand Southern Alps. Geochimica et Cosmochimica Acta, 67, 29-46. https://doi.org/10.1016/S0016-7037(02)01053-0

[49] Liu, S., Lin, G., Liu, Y., Zhou, Y., Gong, F. and Yan, Y. (2007) Geochemistry of Middle Oligocene Pliocene Sandstones from the Nanpu Sag, Bohai Bay Basin (Eastern China): Implications for Provenance, Weathering, and Tectonic Setting. Geochemical Journal, 41, 359-378. https://doi.org/10.2343/geochemj.41.359

[50] Ohta, T. and Arai, H. (2007) Statistical Empirical Index of Chemical Weathering in Igneous Rocks: A New Tool for Evaluating the Degree of Weathering. Chemical Geology, 240, 280-297. https://doi.org/10.1016/j.chemgeo.2007.02.017 
[51] Bhatt, M.I. and Ghosh, S.K. (2001) Geochemistry of 2.51Ga old Rampur Group Pelites, Western Himalayas: Implications from Their Provenance and Weathering. Precambrian Research, 108, 1-16. https://doi.org/10.1016/S0301-9268(00)00139-X

[52] McCurry, P. (1976) The Geology of the Precambrian to Lower Paleozoic Rocks o Northern Nigeria: A Review. In: Kogbe, C.A., Ed., Geology of Nigeria, Elizabethan Publishing Company, Lagos, 15-39.

[53] Wronkiewicz, D.J. and Condie, K.C. (1987) Geochemistry of Archean Shales from the Witwatersrand Supergroup, South Africa: Source-Area Weathering and Provenance. Geochimica et Cosmochimica Acta, 51, 2401-2416. https://doi.org/10.1016/0016-7037(87)90293-6

[54] Suttner, L.J. and Dutta, P.K. (1986) Alluvial Sandstones and Paleoclimate: Framework Mineralogy. Journal of Sedimentary Petrology, 56, 329-345.

[55] Schmitz, B., Charisi, S.D., Thompson, E.I. and Speijer, R.P. (1997) Barium, $\mathrm{SiO}_{2}$ (Excess) and $\mathrm{P}_{2} \mathrm{O}_{5}$ as Proxies of Biological Productivity in the Middle East during the Paleocene and the Latest Paleocene Benthic Extinction Event. Terra Nova, 9, 95-99. https://doi.org/10.1111/j.1365-3121.1997.tb00011.x

[56] Van Os, B.J., Middelburg, J.J. and de Lange, G.J. (1991) Possible Diagenetic Mobilization of Barium in Sapropelic Sediments from the Eastern Mediterranean. Marine Geology 100, 125-136. https://doi.org/10.1016/0025-3227(91)90229-W

[57] Van, B.P., Reyss, J.L., Bonte, P. and Schmidt, S. (2003) Sr/Ba in Barite: A Proxy of Barite Preservation in Marine Sediments? Marine Geology, 199, 205-220.

https://doi.org/10.1016/S0025-3227(03)00220-2 